\title{
Lending Relationships and the Effect of Bank Distress: Evidence from the 2007-2009 Financial Crisis
}

\author{
Daniel Carvalho, Miguel A. Ferreira, and Pedro Matos*
}

\begin{abstract}
We study the transmission of bank distress to nonfinancial firms from 34 countries during the 2007-2009 financial crisis using systemic and bank-specific shocks. We find that bank distress is associated with equity valuation losses and investment cuts to borrower firms with the strongest lending relationships with banks. The losses are not offset by borrowers' access to public debt markets and are concentrated in firms with the greatest information asymmetry problems and weakest financial positions. Our findings suggest that public debt markets do not mitigate the effects of relationship bank distress during financial crises.
\end{abstract}

\section{Introduction}

The 2007-2009 worldwide financial crisis has renewed interest in understanding the consequences of shocks to the financial health of banks for nonfinancial firms. If borrowing firms are unable to substitute between bank credit and other sources of external financing, firms can become bank dependent, and shocks to the financial health of banks can impose significant costs on the nonfinancial sector through restrictions on the supply of credit (e.g., Bernanke (1983), Holmstrom and Tirole (1997)).

What determines firms' degree of bank dependence and exposure to banking shocks? What explains differences in the cost of these shocks across firms?

\footnotetext{
*Carvalho (corresponding author), daniel.carvalho@marshall.usc.edu, University of Southern California, Marshall School of Business, Los Angeles, CA 90089; Ferreira, miguel.ferreira@ novasbe.pt, Universidade Nova de Lisboa, Nova School of Business and Economics, Lisboa 1099-032, Portugal; and Matos, matosp@darden.virginia.edu, University of Virginia, Darden School of Business, Charlottesville, VA 22906. We thank for helpful comments an anonymous referee, Murillo Campello, Sudheer Chava, Qinglei Dai, Harry DeAngelo, Isil Erel, Victoria Ivashina, Paul Malatesta (the editor), Oguzhan Ozbas, Marco Pagano, Daniel Paravisini, Manju Puri, Lori Santikian, João Santos, David Scharfstein, Philipp Schnabl, Jeremy Stein, Phil Strahan, Amir Sufi, and David Yermack; conference participants at the 2011 Western Finance Association Meeting, 2011 Financial Intermediation Research Society Annual Conference, 2012 North American Winter Meeting of the Econometric Society, 2012 Banco de Portugal Conference on "Economic Development in the European Context," and the 2010 California Corporate Finance Conference; and seminar participants at ESSEC-Paris, Tilburg University, Universidade Nova de Lisboa, University of Rotterdam, and University of Southern California. We thank John Bai for excellent research assistance. Financial support from the European Research Council is gratefully acknowledged.
} 
Previous studies argue that firms' ability to access public debt markets is an important determinant of their degree of bank dependence: It allows firms to substitute bonds for bank loans and reduce their exposure to drops in the supply of bank lending (e.g., Kashyap, Lamont, and Stein (1994), Bernanke (2007), Leary (2008), and Chava and Purnanandam (2011)). ${ }^{1}$

In this article, we examine the cross-sectional determinants of bank dependence during the 2007-2009 financial crisis. The goal is twofold. First, we test the hypothesis that stronger lending ties with banks lead to greater bank dependence by reducing firms' ability to substitute relationship bank loans with other sources of external financing. Our hypothesis is motivated by the idea that banks can reduce the cost of lending by developing mutually beneficial relationships with firms through the accumulation of proprietary information about firms that is not easily transferable (e.g., Diamond (1984), (1991), Petersen and Rajan (1994), (1995)). Although strong relationships with firms can allow banks to have longer horizons and insulate firms from short-term adverse conditions (Hoshi, Kashyap, and Scharfstein (1990)), distressed banks might not have resources to do so. Additionally, distressed banks might have incentives to act opportunistically and exploit their informational advantage over other suppliers of capital (Sharpe (1990), Rajan (1992), and Boot, Greenbaum, and Thakor (1993)). ${ }^{2}$ Because most firms in the overall economy do not have access to public capital markets, it is important to understand other determinants of bank dependence.

Second, we examine whether firms' ability to access public debt markets insulates firms from bank distress during a period of large aggregate losses to financial institutions and large aggregate drops in bank loans. Indeed, the ability of public debt markets to offset credit supply shocks may be mitigated during periods when multiple firms want to access public markets at the same time. Figure 1 shows the quarterly change in outstanding debt to U.S. nonfinancial firms partitioned by bank loans and public debt (commercial paper and corporate bonds). The figure shows a dramatic decrease in bank loans during 2008 and 2009 that was not matched by a comparable increase in public debt. Consistent with the view that public debt markets became more expensive during this period, Figure 2 shows a significant increase in credit spreads as measured by the spread between the yield of Moody's Baa-rated U.S. corporate bonds and the long-term U.S. government bond yield (Ibbotson (2009)). To the extent that an important part of these changes reflects the supply of credit (Ivashina and Scharfstein (2010)), public markets may have a limited ability to insulate firms from the cost of these shocks.

In a sample of 1,564 publicly traded firms from 34 countries, we measure lending relationships between banks and firms, looking at a large set of bank loans

\footnotetext{
${ }^{1}$ Kashyap, Stein, and Wilcox (1993) and Becker and Ivashina (2014) also provide evidence of this substitution from bank loans to bonds.

${ }^{2} \mathrm{~A}$ caveat to our hypotheses is the possibility that firms anticipate the possibility of banks' distress and choose their current lending relationships to mitigate this cost. Detragiache, Garella, and Guiso (2000) present a model in which firms expecting greater loss from relationship bank distress choose a greater number of relationship banks in equilibrium. This effect could mitigate and possibly invert the sign of the observed relation between the strength of lending relationships and the cost of bank distress.
} 


\section{FIGURE 1}

\section{Net Funds Raised in Public Debt and Bank Loans by U.S. Nonfinancial Firms}

Figure 1 shows 4-quarter rolling-window average change in outstanding debt to nonfarm nonfinancial firms obtained from the U.S. Flow of Funds Accounts quarterly data (1980:Q1-2009:Q4). Bank and Other Loans is the sum of the items "Other Loans and Advances" and "Bank Loans Not Elsewhere Classified." Commercial Paper and Corporate Bonds is the sum of the items "Commercial Paper" and "Corporate Bonds."

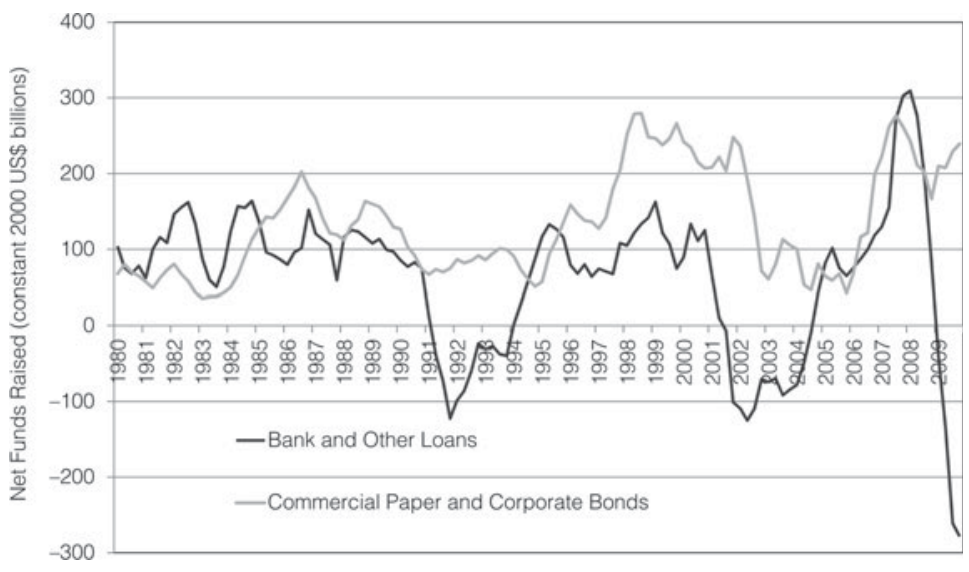

FIGURE 2

\section{Credit Spread}

Figure 2 shows the spread between the monthly yield of Moody's Baa-rated U.S. corporate bonds and the long-term U.S. government bond yield from 1980 to 2009 .

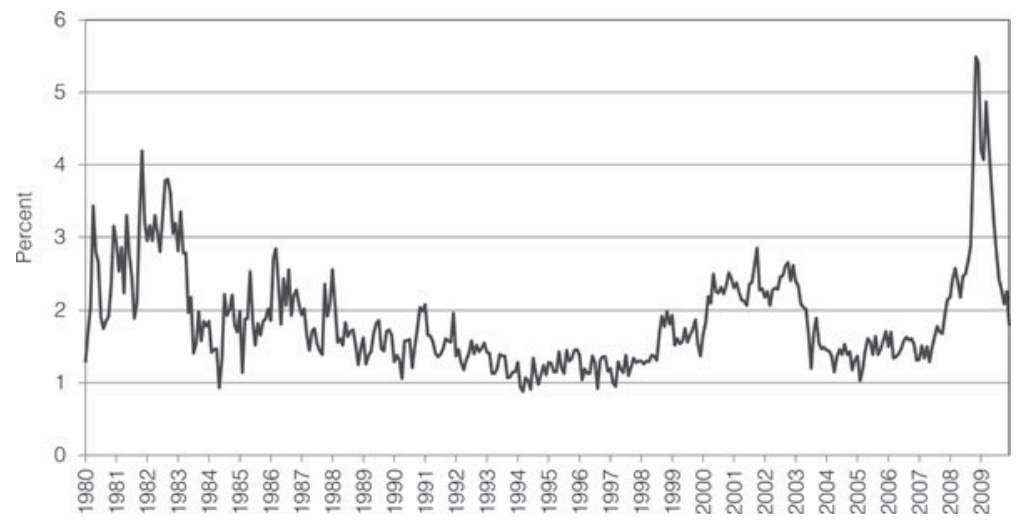

initiated before the crisis. We first analyze the link between relationship bank distress and borrower firm equity value for the average firm in our sample. Most of the loans in our sample are syndicated, and we focus on the relationship between firms and lead arranger banks. ${ }^{3}$ Our identification strategy exploits periods when

\footnotetext{
${ }^{3}$ Previous evidence from the syndicated loan market supports the importance of lending relationships. Bharath, Dahiya, Saunders, and Srinivasan (2007) show that relationship lenders are much more likely to provide future loans. Bharath, Dahiya, Saunders, and Srinivasan (2011) show that firms pay lower spreads when they borrow from relationship lenders.
} 
banks experienced major but different levels of unexpected distress. We compare changes in the value of borrower firms in the same country and period, conditional on several firm-level controls, and relate them to relationship bank distress, captured by changes in the equity value of their main banks over the same period.

We base our analysis on two types of events. First, we use the collapse of the investment banks Lehman Brothers and Bear Stearns and the diverse effects it produced across banks. Second, we use asset write-downs for individual banks. We interpret the occurrence of write-downs in a given week as a source of new information on banks' financial health and estimate the link between firms and their main banks' equity valuation in that week. In both approaches, we find an economically and statistically significant link between borrower firm abnormal returns and main bank abnormal returns. As a benchmark, we estimate the same relation in a sample where banks experienced no write-downs and find no link. This provides support that our findings are not driven by selection: Firms borrowing from banks that experience greater losses are inherently different from other firms. ${ }^{4}$ Furthermore, the relation is important only among firms whose main banks are more exposed to the U.S. market, which is consistent with the idea that for this group of banks, returns are more likely to reflect information about shocks to banks' financial health. This finding suggests that the effect of bank distress is driven by the international propagation of shocks from U.S.-exposed banks to the rest of the world.

We then estimate the relation between borrower firm returns and main bank returns separately for different groups of firms. We first analyze how this effect is related to the strength of firms' lending relationships, which is defined as those firms with a greater concentration of past lending with main banks. We find that our results are important only among firms with the strongest lending relationships. When we analyze the other side of this relationship, from the viewpoint of banks (Dahiya, Saunders, and Srinivasan (2003)), we find that results are stronger for firms that represent the lowest share of banks' loan portfolios. This provides support that our results are driven by the effect of main bank distress on firms and not the reverse.

We next examine whether the firms' ability to access public debt markets allows firms to offset the cost of main bank distress. We look at firms' bond market issuance activity before the 2007-2009 financial crisis and show that the effect of banks distress is not economically or statistically different depending on borrowers' access to public debt markets. In addition, we show that our main results are virtually identical in the sample of U.S. firms, which have access to the most liquid bond markets in the world. For U.S. firms, the effect of main bank distress is not different depending on the existence of a bond or commercial paper rating before the crisis. These results suggest that public debt markets played a limited role in mitigating the cost of bank distress for borrowing firms during the recent

\footnotetext{
${ }^{4}$ Abnormal bank returns in the average week might capture not only news about bank distress but also news about discount rates, liquidity, or cash-flow news about banks. Because we are able to single out the periods when there was important news about the financial health of specific banks, if bank distress matters for relationship firms, we expect to see a stronger relation between bank returns and firm returns during these periods and for these specific banks.
} 
financial crisis. A possible explanation for this different finding may be the stark contrast in the magnitude of the aggregate change in bank loans during the recent financial crisis versus the 1998 Russian crisis, which can be seen in Figure 1.

We refine the analysis in different ways. We find that different measures of stronger lending ties lead to the same conclusions and that these measures do not predict greater valuation losses for firms when their main banks are not distressed. This finding alleviates the concern that lending relationships are simply capturing some omitted factor.

We then analyze the role of borrower information asymmetry. We find that the results are important only for firms expected to face the greatest information asymmetry problems (smallest firms and those with the least analyst coverage). Moreover, the results are driven by firms that both have strong lending relationships and are more likely to face information asymmetry problems.

If distress in main banks affects firms through an increase in the cost of external financing, then the financial position of firms at the time of a shock should matter. Recent work shows that firms with weaker financial positions during the financial crisis have been the most affected by the crisis (e.g., Duchin, Ozbas, and Sensoy (2010), Almeida, Campello, Laranjeira, and Weisbenner (2012)). In our tests, we provide evidence that firms with little leverage and high cash holdings at the time of the shock are not affected by main bank distress.

Finally, we provide evidence that bank distress is associated with effects on real corporate behavior. We find that firms that relied more on lending relationships before the crisis cut annual investment by a greater amount during the crisis than otherwise similar firms. This effect is economically important and significant only for firms that both have strong lending relationships with banks and are small. We also find evidence that the ability to access public debt markets does not allow firms to offset investment drops during periods of large drops in bank loans.

Our study is related to a large literature examining the effect of shocks to the financial position of banks on borrowing firms that have prior relationships with banks. Recent papers have used micro data from credit registries in emerging markets, allowing them to more precisely identify shocks to the supply of credit, as well as study the consequences of these shocks for relationship firms (e.g., Khwaja and Mian (2008), Paravisini (2008), and Schnabl (2012)).

Other studies analyze the valuation effects of bank loan supply shocks. Slovin, Sushka, and Polonchek (1993) provide evidence that the near collapse of Continental Illinois negatively affected 29 clients with which the bank had a lending relationship as a direct lender or lead arranger, and Fernando, May, and Megginson (2012) provide evidence that the Lehman collapse negatively affected clients to which the bank provided equity underwriting services. Chava and Purnanandam (2011) find that firms without access to public debt markets (proxied by the absence of credit rating) experienced greater valuation losses during the 1998 Russian crisis. ${ }^{5}$

\footnotetext{
${ }^{5}$ Previous work also examines credit supply during financial crises (e.g., Bernanke (1983), Bae, Kang, and Lim (2002), Ongena, Smith, and Michalsen (2003), Calomiris and Mason (2003), and Campello, Giambona, Graham, and Harvey (2011)), but does not examine the role of lending
} 
We complement previous research in several ways. First, we provide direct support for the view that the strength of firms' lending ties with banks is a key determinant of the degree of bank dependence and the cost of main bank distress. This evidence complements previous work examining the benefits and costs of lending relationships (e.g., Petersen and Rajan (1994), (1995)). Second, we examine cross-sectional determinants of the link between main bank distress and borrower firm equity value using a large sample of firms in countries with welldeveloped capital markets. This sample helps to shed light on the mechanisms behind credit supply shock transmission to the real economy and helps with identification as institutional differences are exogenous. Finally, we show that public debt markets can play a limited role in offsetting the effects of shocks to banks' financial health for borrowing firms during financial crises.

\section{Data}

\section{A. Data Sources and Sample}

We start by identifying publicly listed firms that have syndicated bank loans using DealScan. We include all loans initiated before the financial crisis, between Jan. 2003 and Dec. 2006. We exclude from the sample: i) loans in which the borrower is a financial firm (Standard Industrial Classification (SIC) codes 60006999), a utility company (SIC codes 4910 and 4940), or a company in the public sector (SIC codes 9000-9999); ii) deals with amounts below $\$ 100$ million for the sum of the tranches (amounts converted to U.S. dollars when they are in a different currency); and iii) loans without information on all-in drawn spread. This provides us with an initial sample of 21,806 loan facilities between Jan. 2003 and Dec. 2006.

We restrict our sample to borrower firms that have financial information from Worldscope as of 2006. We merge the DealScan and Worldscope data sets using the firm's country and ticker; when these data fields are unavailable, we manually match the item "Borrower-Parent" in DealScan with the company names in Worldscope. Only firms that we are able to identify using this procedure are included in our sample. Most loans in our sample are syndicated, often involving several banks as lead arrangers and lenders. Although lead arranger banks retain only a part of the loan, they take primary responsibility for ex ante due diligence and ex post monitoring of the borrower. Given the moral hazard and adverse selection problems between lead arrangers and other participants, firms are able to obtain financing from third parties only after informed parties (lead arrangers) take large financial stakes (Sufi (2007)). Therefore, we focus on lending relationships between firms and their lead arranger banks, whose responsibilities best fit the description of a relationship lender.

We classify banks as lead arrangers in a given loan according to the variable "Lenders-Lead Arrangers" from DealScan. ${ }^{6}$ We treat all loans granted by

relationships. Puri, Rocholl, and Steffen (2011) examine retail lending during the crisis and find that bank-depositor relationships help mitigate credit supply shocks.

${ }^{6}$ This approach is the same as the one used by Sufi (2007) except that we do not use other information to classify the lead arranger when "Lenders-Lead Arrangers" is missing. However, the number of observations for which this is an issue in our sample is less than $0.4 \%$ of the overall sample. 
a subsidiary or a branch of a bank as loans originating from the same parent bank. ${ }^{7}$ To determine the top parent banks worldwide, we manually merge the lead arranger banks in DealScan with the list of "Top World Banks" published by The Banker (http://www.thebanker.com/Top-1000), which ranks the world's leading commercial banks by Tier 1 capital. ${ }^{8}$ To make the data collection manageable but still retain most of the loans, we choose the top 20 lead arranger banks operating in each country, as ranked by volume of loans arranged for firms headquartered in that country. The final sample consists of 136 different banks in the countries where borrower firms in our sample operate. This leaves us with 20,775 facilities during 2003-2006.

The next step is to determine the main (lead arrangers) banks for each firm during the precrisis period (2003-2006). Because loan shares are not available for most of our sample, we compute the amount of the loan allocated to bank $b$ by allocating pro rata the total value of the loan across all banks in the loan. For each firm $i$ and bank $b$ in our sample, we then compute the total amount of loans to firm $i$ from bank $b$ during 2003-2006. We define the lending share $(i, b)$ as the ratio of this amount to the total amount of loans to firm $i$ during that period. For each firm, we identify the main bank as the bank $b$ that has the higher value of share $(i, b)$. For $62.1 \%$ of the firms in our sample, we identify only one main bank during 2003-2006 (33.3\% of the firms have only one bank). If two banks have an equal amount of loans, we count them as multiple main banks. For $37.9 \%$ of our sample we identify more than one main bank. Our results are robust to alternative approaches to defining the lending share $(i, b)$ and main banks, such as using numbers of loans or allocating loan amounts entirely to all banks.

Finally, we use Datastream to obtain stock return data for borrower firms and main banks during the crisis period (July 2007 to Oct. 2008). For each firm, bank, and period, we compute abnormal returns as the market-model-adjusted returns. ${ }^{9}$ For firms with more than one main bank, we compute bank abnormal returns as the equally weighted average among all main banks. The results are robust to using raw returns for banks and firms. The results are also robust to using a measure of bank returns for each firm that averages across all banks and uses the lending share of each bank for that firm as a weight.

The final sample consists only of firms with at least one main bank that is publicly traded. This leaves us with a final sample of 1,564 publicly listed nonfinancial borrower firms from 34 countries, of which 906 are U.S. firms and 658 are non-U.S. firms.

\footnotetext{
${ }^{7}$ For example, we classify loans arranged by bank branches like Santander Brasil and wholly owned subsidiaries like Abbey National as loans made by Santander.

${ }^{8}$ Of a total of 1,232 different lead arrangers in syndicated loans during 2003-2006, 852 are affiliated with and matched to the top 500 banks. The top 500 lead arranger banks are responsible for $90 \%$ of the volume and $88 \%$ of the number of syndicated loans during 2003-2006.

${ }^{9} \mathrm{We}$ follow standard event-study methodology to compute the market-model-adjusted return. For each firm or bank, we estimate the market-model beta using 250 trading days, ending 50 trading days before the event window. We then compute abnormal returns as raw return minus beta times market return. We use local market returns to estimate the market model but test the robustness of other approaches such as using regional or world factors to account for the fact that firm and bank may be from different countries. Because our identification is based on comparing returns for multiple firms over the same period, we find that our results are not sensitive to the choice of approach.
} 


\section{B. Variables and Summary Statistics}

Panel A of Table 1 reports information on the number of firms in our sample and the top three lead arranger banks operating in the syndicated loan market in each country. We see that both local and global banks are operating in different national markets.

Panel B of Table 1 reports summary statistics for the sample of borrower firms. Firm-level variables are measured at the end of 2006, except for LEVERAGE_2007 and SHORT_LEVERAGE_2007. ASSETS is total assets in millions of U.S. dollars (Worldscope item 02999). MARKET_TO_BOOK is market value of equity divided by book value of equity (Worldscope item 08001/item 03501). LEVERAGE is total debt divided by total assets (Worldscope item 03255/item 02999). SHORT_LEVERAGE is short-term debt divided by total assets (Worldscope item 03051/item 02999). CASH is cash and short-term investments divided by total assets (Worldscope item 02001/item 02999). STOCK_VOLATILITY is the annualized standard deviation of stock returns estimated with 1 year of daily

TABLE 1

\section{Summary Statistics}

Panel $\mathrm{A}$ of Table 1 reports the number of firms and top three lead arranger banks based on syndicated loans during 2003-2006 by country. Panel B reports summary statistics for the sample of firms. ASSETS, MARKET_TO_BOOK, LEVERAGE, CASH, STOCK_VOLATILITY and NUMBER_ANALYSTS are measured at the end of 2006. LEVERAGE_2007 and SHORT_LEVERAGE_2007 are measured at the end of 2007. BOND_ISSUE equals 1 if the firm has issued public bonds in 2003-2006. SHARE_BOND_ISSUES is the ratio of the volume of public bond issues to total volume of syndicated loans and public bond issues in 2003-2006. NUMBER_MAIN_BANKS is the number of banks with the highest share of loans to a firm in the syndicated loan market during 2003-2006. SHARE_VOLUME and SHARE_NUMBER is the ratio of the amount or number of loans from the main bank to total loans to a firm in the syndicated loan market during 2003-2006. HERFINDAHL. VOLUME and HERFINDAHL_NUMBER is the Herfindahl index of lending shares based on amount or number of loans to a firm in the syndicated loan market during 2003-2006. Panel C reports summary statistics of firms' stock returns (FIRM_RETURN) and their main banks' stock returns (BANK_RETURN) during the period of the Bear Stearns and Lehman Brothers failures (Mar. 13, 2008 to Mar. 20, 2008 and Sept. 4, 2008 to Sept. 18, 2008) and the period of the U.S. bailout (Oct. 9, 2008 to Oct. 16, 2008)

Panel A. Number of Firms and Top Lead Arranger Banks in the Syndicated Loan Market

\begin{tabular}{|c|c|c|c|c|}
\hline \multirow[b]{2}{*}{ Country } & \multirow{2}{*}{$\begin{array}{l}\text { No. of } \\
\text { Firms } \\
\end{array}$} & \multicolumn{3}{|c|}{ Top Lead Arranger Banks } \\
\hline & & 1 & 2 & 3 \\
\hline Australia & 40 & National Australia Bank & Commonwealth Bank & ANZ Banking Group \\
\hline Brazil & 13 & ABN AMRO Bank & Santander & UBS \\
\hline Canada & 50 & Royal Bank of Canada & Citigroup & Scotiabank \\
\hline Finland & 17 & Nordea Bank & Citigroup & Barclays Bank \\
\hline France & 64 & BNP Paribas & Credit Agricole & Societe Generale \\
\hline Germany & 40 & Citigroup & Deutsche Bank & JPMorgan Chase \\
\hline Hong Kong & 15 & HSBC & BNP Paribas & Credit Agricole \\
\hline India & 15 & Credit Agricole & ABN AMRO Bank & Standard Chartered \\
\hline Italy & 18 & UniCredit & Banca Intesa & JPMorgan Chase \\
\hline Japan & 22 & Citigroup & Royal Bank of Scotland & Mitsubishi Tokyo Financial \\
\hline Korea (South) & 26 & Citigroup & Kookmin Bank & Woori Bank \\
\hline Malaysia & 14 & Barclays Bank & Standard Chartered & HSBC \\
\hline Mexico & 12 & Citigroup & Banco Bilbao Vizcaya Argentaria & HSBC \\
\hline Netherlands & 26 & ABN AMRO Bank & ING Bank & Citigroup \\
\hline Norway & 12 & DnB NOR & Nordea Bank & Citigroup \\
\hline Spain & 25 & Santander & Royal Bank of Scotland & Citigroup \\
\hline Sweden & 27 & Nordea Bank & Skandinaviska Enskilda & Svenska Handelsbanken \\
\hline Switzerland & 13 & Deutsche Bank & JPMorgan Chase & Barclays Bank \\
\hline Taiwan & 32 & Chinatrust Financial & Fubon Financial & Cathay United Bank \\
\hline Thailand & 10 & Deutsche Bank & Citigroup & ABN AMRO Bank \\
\hline United Kingdom & 110 & Royal Bank of Scotland & Barclays Bank & HSBC \\
\hline United States & 906 & JPMorgan Chase & Citigroup & Bank of America \\
\hline Other & 57 & & & \\
\hline
\end{tabular}




\begin{tabular}{|c|c|c|c|c|c|c|c|c|c|}
\hline \multicolumn{10}{|c|}{$\begin{array}{l}\text { TABLE } 1 \text { (continued) } \\
\text { Summary Statistics }\end{array}$} \\
\hline & & All Firms & & & U.S. Firms & & No & n-U.S. Firm & \\
\hline & Mean & Std. Dev. & $\begin{array}{c}\text { No. of } \\
\text { Obs. }\end{array}$ & Mean & Std. Dev. & $\begin{array}{c}\text { No. of } \\
\text { Obs. }\end{array}$ & Mean & Std. Dev. & $\begin{array}{l}\text { No. of } \\
\text { Obs. } \\
\end{array}$ \\
\hline \multicolumn{10}{|c|}{ Panel B. Summary Statistics on Sample of Firms } \\
\hline ASSETS ( $\$$ millions) & 9,446 & 24,400 & 1,564 & 7,433 & 21,600 & 906 & 12,200 & 27,600 & 658 \\
\hline MARKET_TO_BOOK & 1.823 & 1.593 & 1,545 & 1.881 & 0.951 & 891 & 1.745 & 2.182 & 654 \\
\hline LEVERAGE & 0.289 & 0.206 & 1,563 & 0.290 & 0.237 & 905 & 0.289 & 0.237 & 658 \\
\hline LEVERAGE_2007 & 0.299 & 0.195 & 1,398 & 0.306 & 0.216 & 790 & 0.291 & 0.163 & 608 \\
\hline SHORT_LEVERAGE_2007 & 0.057 & 0.079 & 1,298 & 0.044 & 0.080 & 706 & 0.073 & 0.075 & 592 \\
\hline $\mathrm{CASH}$ & 0.093 & 0.096 & 1,563 & 0.086 & 0.097 & 905 & 0.102 & 0.097 & 658 \\
\hline STOCK_VOLATILITY & 0.308 & 0.549 & 1,564 & 0.281 & 0.156 & 906 & 0.326 & 0.709 & 658 \\
\hline NUMBER_ANALYSTS & 10.247 & 7.820 & 1,564 & 9.535 & 6.944 & 906 & 11.226 & 8.798 & 658 \\
\hline BOND_ISSUE & 0.496 & 0.500 & 1,564 & 0.395 & 0.489 & 906 & 0.568 & 0.496 & 658 \\
\hline SHARE_BOND_ISSUES & 0.189 & 0.247 & 1,564 & 0.212 & 0.247 & 906 & 0.157 & 0.242 & 658 \\
\hline NUMBER_MAIN_BANKS & 1.773 & 1.537 & 1,564 & 1.240 & 0.442 & 906 & 2.509 & 0.442 & 658 \\
\hline SHARE_VOLUME & 0.643 & 0.304 & 1,564 & 0.769 & 0.235 & 906 & 0.468 & 0.302 & 658 \\
\hline SHARE_NUMBER & 0.618 & 0.316 & 1,564 & 0.749 & 0.249 & 906 & 0.436 & 0.308 & 658 \\
\hline HERFINDAHL_VOLUME & 0.611 & 0.318 & 1,564 & 0.722 & 0.267 & 906 & 0.436 & 0.312 & 658 \\
\hline HERFINDAHL_NUMBER & 0.595 & 0.324 & 1,564 & 0.887 & 0.187 & 906 & 0.420 & 0.313 & 658 \\
\hline \multicolumn{10}{|c|}{ Panel C. Summary Statistics of Returns in Systemic Events } \\
\hline \multicolumn{10}{|c|}{ Bear Stearns and Lehman Events } \\
\hline FIRM_RETURN & -0.024 & 0.081 & 4,848 & -0.009 & 0.085 & 2,718 & -0.042 & 0.073 & 2,130 \\
\hline BANK_RETURN & 0.007 & 0.116 & 4,734 & 0.034 & 0.133 & 2,718 & -0.030 & 0.072 & 2,016 \\
\hline \multicolumn{10}{|l|}{ U.S. Bailout Event } \\
\hline FIRM_RETURN & -0.025 & 0.123 & 1,616 & 0.012 & 0.131 & 906 & -0.072 & 0.093 & 710 \\
\hline BANK_RETURN & 0.082 & 0.229 & 1,578 & 0.200 & 0.210 & 906 & -0.077 & 0.139 & 672 \\
\hline
\end{tabular}

stock returns. NUMBER_ANALYSTS is the number of analysts following the firm's stock (the source is Institutional Brokers' Estimate System (IBES)). BOND_ISSUE is a dummy variable that equals 1 if the firm issued a public bond during 2003-2006 (source is Securities Data Company (SDC) Platinum). SHARE_BOND_ISSUES is the ratio of the volume of public bond issues to total volume of syndicated loans and public bond issues during 2003-2006. The average firm in our sample is larger (average of assets is $\$ 9.5$ billion) and has more leverage and less cash than the average firm in Compustat.

NUMBER_MAIN_BANKS is the number of main banks in the syndicated loan market during 2003-2006. The median number of main banks is 1, but the average number of main banks is greater than 1 . The main banks represent the large majority of the loans used by firms in our sample (average is 85.2\%). SHARE_VOLUME for firm $i$ is the ratio of the total amount of loans to firm $i$ from the main banks to the total amount of loans to firm $i$ in the syndicated loan market during 2003-2006. HERFINDAHL_VOLUME for firm $i$ is the Herfindahl index of the lending shares of all banks based on the amount of loans to firm $i$ in the syndicated loan market during 2003-2006. We also calculate SHARE_NUMBER and HERFINDAHL_NUMBER using the number of loans instead of the volume of loans.

\section{Identifying Weeks with Significant News on Bank Losses}

In our first approach we isolate systemic events producing unexpected shocks to the financial health of most banks. Figure 3 shows the daily evolution of credit 


\section{FIGURE 3}

Identifying Systemic Shocks to the Financial Health of Banks

Figure 3 shows daily credit default swap (CDS) spreads for the top five banks in the world according to The Banker ranking from Aug. 2007 to Oct. 2008. The CDS spread is for a contract on senior secured debt with a maturity of 5 years, and the data are obtained from Datastream/Credit Market Analysis. We identify periods (shaded) of systemic shocks to the financial health of banks by a significant increase in CDS spreads at the time of the failure of Bear Stearns and Lehman Brothers, and by a significant decrease in CDS spreads at the time of the U.S. bailout announcement.

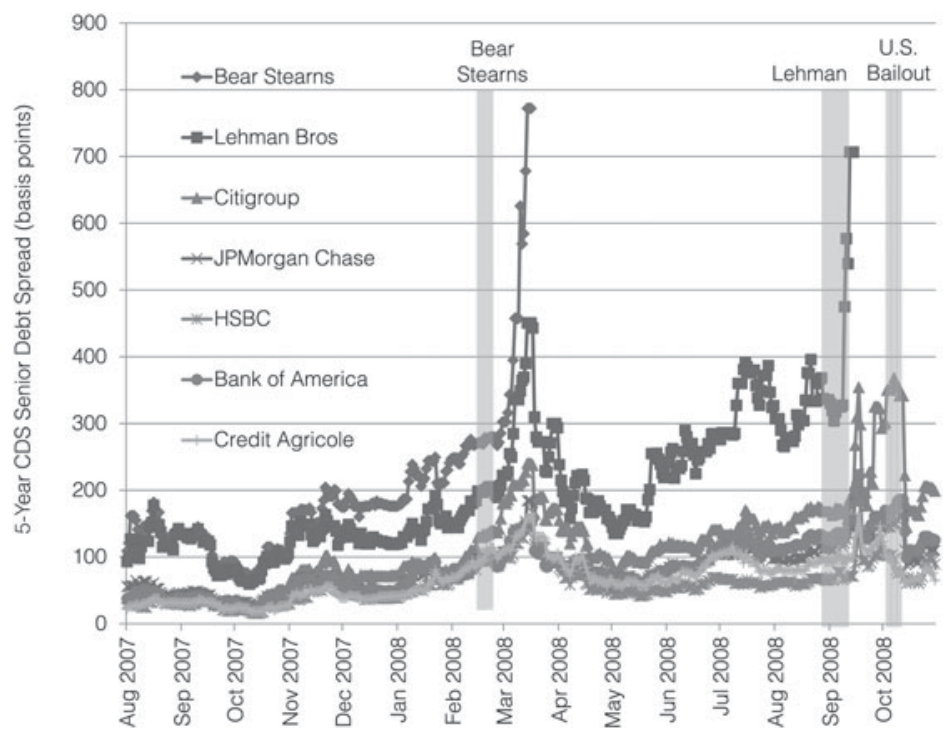

default swap (CDS) spreads for the top five banks in the world according to The Banker ranking (Citigroup, JPMorgan Chase, HSBC, Bank of America, and Credit Agricole) plus Bear Stearns and Lehman Brothers during the crisis period. ${ }^{10}$ The CDS spread is an indication of the level of credit risk, and the failures of Bear Stearns and Lehman Brothers produced the most significant negative shocks during the period, as evidenced by the spikes in the CDS spreads.

We identify the first systemic event as the failure of Bear Stearns, for which we use the period from Mar. 13, 2008 (Thursday) to Mar. 20, 2008 (Thursday). This period centers on the weekend when officials from the Federal Reserve Bank of New York brokered a deal for JPMorgan Chase to acquire Bear Stearns. We identify the second systemic event as the failure of Lehman Brothers, for which we use two periods: Sept. 4, 2008 (Thursday) to Sept. 11, 2008 (Thursday) and Sept. 11, 2008 (Thursday) to Sept. 18, 2008 (Thursday). The first period captures the fall in Lehman's stock price before the last attempts to save it, as it became clear on Sept. 9, 2008 that the Korea Development Bank would not buy Lehman. The second period is centered on the weekend when the president of the Federal Reserve Bank of New York convened a meeting with all major banks' top executives, leading to the announcement of bankruptcy early Monday morning.

\footnotetext{
${ }^{10}$ The spread is for a CDS contract on senior secured debt with a maturity of 5 years for these banks. The data source is Datastream (which sources its data from Credit Market Analysis).
} 
Finally, we use the U.S. bailout as the third systemic event, for which we use the period from Oct. 9, 2008 (Thursday) to Oct. 16, 2008 (Thursday). This period includes the announcement on Monday, Oct. 13, 2008, of the U.S. Treasury Federal Deposit Insurance Corporation (FDIC) plan that included a \$125 billion preferred equity infusion into the 10 largest U.S. commercial banks and a 3 -year government guarantee on new unsecured debt issues. Veronesi and Zingales (2010) provide evidence that this plan reduced bank financial distress.

Panel $\mathrm{C}$ of Table 1 reports summary statistics of firm returns and main bank returns in the systemic events windows. The choice of 5-trading-day windows is motivated by two issues. On the one hand, we do not want to use very short windows, as the market might be slow to incorporate the consequences of bank distress for their relationship clients (Cohen and Frazzini (2008)). On the other hand, shorter windows allow us to use higher frequency information on the financial condition of banks. For example, over a 10-trading-day period, the market perceptions about the financial health of banks might worsen and improve to original levels (see Figure 3). In untabulated tests we find that our results are robust to other windows such as 3 or 10 trading days.

In our second approach we isolate bank-specific events. The period of analysis is between July 27, 2007 (Friday) and Oct. 10, 2008 (Friday). It starts before July 30, 2007, when two Bear Stearns hedge funds that had invested in subprime mortgages filed for bankruptcy, and ends before Oct. 13, 2008, when the bailout of the largest U.S. banks was announced.

We rely on public announcements of asset write-downs by individual banks during the crisis period. The data source is Bloomberg, which introduced the WDCI function to track financial firms' asset impairments during the crisis. ${ }^{11}$ The total losses amounted to $\$ 1,073$ billion from the first quarter of 2007 through the fourth quarter of 2008. The majority of these losses are related to mortgagebacked securities (MBS) (e.g., collateralized debt obligations, subprime residential MBS, and commercial MBS). We merge the financial firms in the Bloomberg WDCI data with the list of 136 banks in our sample that acted as top lead arrangers. Of these 136 banks, 73 have write-down data, for a total of 167 writedown announcements. Figure 4 shows the total number of write-down announcements by individual banks per calendar week. In the 64 calendar weeks between July 27, 2007 and Oct. 10, 2008, there are 50 weeks with announcements and 14 weeks without announcements. The week of Aug. 4, 2008 to Aug. 10, 2008 saw the most announcements, with a total of 17 banks in our sample announcing asset write-down news.

Some of our tests are based on the stock market reaction to write-down announcements by banks. For each write-down, we compute the market-modeladjusted abnormal return of the bank between the day before and the day after the event. This captures the market's update on a bank's financial health. The distribution of abnormal returns around write-downs supports the view that most of the new information on banks is captured by the variation of returns across events, as

\footnotetext{
${ }^{11}$ According to Bloomberg, this function was so popular that on some days in 2008 , more than 10,000 users monitored WDCI.
} 
FIGURE 4

Identifying Bank-Specific Shocks to the Financial Health of Banks

Figure 4 shows the number of bank asset write-down announcements per calendar week from Aug. 2007 to Oct. 2008 The data are obtained from the WDCI function in Bloomberg, which was introduced for investors to track financial firms asset impairments and credit losses during the crisis. We identify periods of bank-specific shocks to the financial health of banks based on bank asset write-downs.

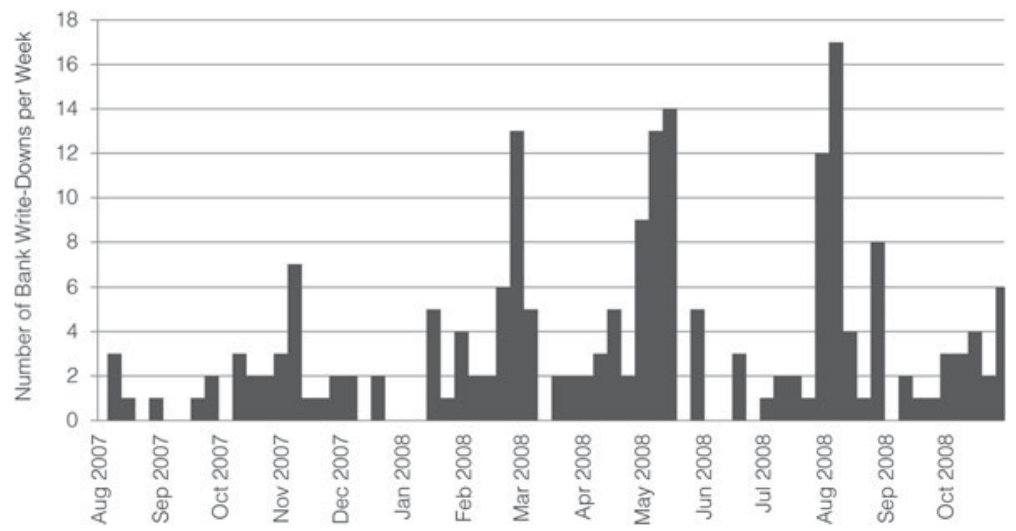

opposed to an average effect. The mean and median abnormal returns are, respectively, $-0.73 \%$ and $-0.15 \%$. The standard deviation of returns is $7.19 \%$.

\section{The Effect of Relationship Bank Distress}

In this section, we examine the link between main bank distress and borrower equity valuation across all firms in the sample. We implement this analysis in periods when main banks experienced unexpected shocks to their financial health.

\section{A. Results Using Systemic Events}

We focus on the collapse of Bear Stearns in Mar. 2008 and Lehman Brothers in Sept. 2008, and explore how these events affected other banks. We interpret these events as providing new information on the quality of assets held by other financial institutions, their financial health, and their counterparties' risk, as well as generating uncertainty about the financial sector, which is amplified through mechanisms such as asset fire sales, liquidity problems, and complexity in financial networks. ${ }^{12}$ There are many reasons for heterogeneous bank losses, including different asset holdings, exposure to different counterparties, and different financial positions at the time of the shock. We use changes in banks' equity value during this period to capture changes in bank distress. We then relate bank returns and firm returns during systemic shock event dates.

We estimate the following equation:

(1) FIRM_RETURN $i t c=\alpha_{t c}+\beta \times$ BANK_RETURN $_{i t c}+\delta \times X_{i c}+\varepsilon_{i t c}$,

\footnotetext{
${ }^{12}$ See Brunnermeier (2009) and Gorton and Metrick (2012) for more detailed discussions.
} 
where FIRM_RETURN is the market-model-adjusted abnormal return of firms over period $t, \alpha_{t c}$ is a country-by-time fixed effect, BANK_RETURN is the average market-model-adjusted abnormal return of firm $i$ main bank or banks; and $X_{i c}$ are firm-level controls (assets, market-to-book, leverage, cash, stock volatility, share of main bank volume during 2003-2006, share of bond issues during 2003-2006, and 1-digit SIC industry fixed effects) measured before the crisis period at the end of 2006. All reported standard errors are robust to heteroskedasticity and clustered at the firm level. When we estimate equation (1), we are relating firm returns to bank returns for each country and period separately, and then averaging these effects across all countries and periods.

Panel A of Table 2 reports the estimates of equation (1) using the three 1-week systemic event windows (failure of Bear Stearns and Lehman Brothers). Column 1 reports a positive and statistically significant relation between firms' abnormal stock returns and the abnormal return of their main banks. This finding indicates that borrowers whose main bank has been more negatively affected by the systemic shocks earn lower returns. The regression coefficient implies that a $100 \%$ decline in main banks' equity valuations is associated with a reduction in firms' equity valuation by $5.61 \%$. To evaluate the economic significance of the effect, we can take the average stock return of the banks in our sample during the crisis period. A $40 \%$ decline in the main banks' equity valuation (the average realized stock return from July 27, 2007 through Oct. 10, 2008) is associated with a reduction in borrower equity valuation of $2.24 \%$ for the average firm in our sample. We see below that this effect is heterogeneous across firms. ${ }^{13}$

In column 2 of Table 2 we use an alternative set of controls. We control for nonlinearities in the relation between firm-level controls and the firm's stock's abnormal return by using indicator variables based on the terciles of the distribution of each firm characteristic. We also include industry indicators at the 2-digit SIC level instead of indicators at the 1-digit SIC level. In column 3 we control for main bank total valuation loss during the financial crisis. For each firm, we compute the average cumulative abnormal return of the firm's main banks from July 27, 2007 through Oct. 10, 2008. We then include indicator variables based on the quartiles of the distribution of this total bank loss. In this specification, we are identifying the effect based on the timing of bank losses. In a given period, we are comparing only firms with main banks that experienced a similar overall loss during the financial crisis but that experienced different losses during the specific period. In both approaches, we find a positive and significant coefficient on banks' abnormal returns, and one similar to the base case in column 1 .

Main bank returns are more likely to reflect information about shocks to banks' financial health for banks more exposed to the U.S. market. To test this idea, we compute the firm's main bank exposure to the U.S. market. For each bank $i$, we calculate the share that the volume of loans to U.S. firms represent of the total volume of loans arranged by bank $i$ in the syndicated loan market during 2003-2006; then, for each firm $j$, we average this share across all main banks. In column 4 of Table 2 we include the interactions of main bank returns with the

\footnotetext{
${ }^{13}$ We obtain similar estimates of the effect of bank distress when we estimate equation (1) separately for the Bear Stearns and Lehman events but the estimates have lower precision.
} 
TABLE 2

Firm Returns and Main Bank Returns: Systemic Events Results

Table 2 reports coefficient estimates from regressions relating firms' stock returns to their main banks' stock returns in the syndicated loan market in the weeks of the Bear Stearns and Lehman Brothers failures (Mar. 13, 2008 to Mar. 20, 2008 and Sept. 4, 2008 to Sept. 18, 2008; Panel A) and the U.S. bailout (Oct. 9, 2008 to Oct. 16, 2008; Panel B). The dependent variable is the firm's market-model abnormal return, and the main independent variable is the average marketmodel abnormal return of the firm's main banks. US_BANK is a dummy that equals 1 if the firm's main banks U.S. exposure is in the top half of the distribution. NON_US_BANK is a dummy that equals 1 if the firm's main banks U.S. exposure is in the bottom half of the distribution. Main banks U.S. exposure is computed as follows: For each bank $i$, calculate the share that the volume of loans to U.S. firms represents of the total volume of loans arranged by bank $i$ in the syndicated loan market during 2003-2006; then, for each firm j, average this share across all main banks. Controls (coefficients not shown) are measured at the end of 2006 and include assets, market-to-book, leverage, cash, stock volatility, share of main bank volume during 2003-2006, share of bond issues during 2003-2006, and 1-digit Standard Industrial Classification (SIC) industry fixed effects. Alternative controls include indicator variables based on the terciles of the distribution of each control variable and 2-digit SIC industry fixed effects. The bank total loss group fixed effects sort firms into four groups based on the average cumulative abnormal return of their main banks between July 27, 2007 and Oct. 10, 2008. Robust standard errors clustered at the firm level are reported in parentheses. ${ }^{* *}$ and ${ }^{* * *}$ indicate significance at the $5 \%$ and $1 \%$ levels, respectively.

Panel A. Bear Stearns and Lehman Events

BANK_RETURN

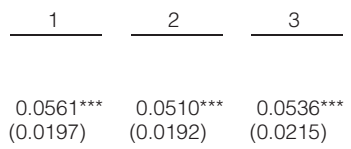

BANK_RETURN $\times$ US_BANK

$\begin{array}{lll}0.0197) & (0.0192) \quad(0.0215)\end{array}$

BANK_RETURN $\times$ NON_US_BANK

Controls

Alternative controls

Country $\times$ Time fixed effect

Country $\times$ Bank total loss group $\times$ Time fixed effect

Country $\times$ U.S. bank $\times$ Time fixed effect

No. of obs.

$R^{2}$

Panel B. U.S. Bailout Event

BANK_RETURN

BANK_RETURN $\times$ US_BANK

BANK_RETURN $\times$ NON_US_BANK

Controls

Alternative controls

Country $\times$ Time fixed effects

Country $\times$ Bank total loss group $\times$ Time fixed effects

Country $\times$ U.S. bank $\times$ Time fixed effects

No. of obs.

$R^{2}$

$\begin{array}{cc}0.0601^{* * *} & 0.0610^{* * \star} \\ (0.0215) & (0.0231) \\ 0.0256 & 0.0265 \\ (0.0293) & (0.0303) \\ \text { Yes } & \text { Yes } \\ \text { Yes } & \text { Yes } \\ & \text { Yes } \\ 4,635 & 4,635 \\ 0.05 & 0.05\end{array}$

$\begin{array}{ccc}0.0767^{\star \star \star} & 0.0769^{\star \star \star} & 0.0809^{\star \star} \\ (0.0309) & (0.0309) & (0.0368)\end{array}$

\begin{tabular}{cc}
$0.0767^{\star *}$ & $0.0763^{* *}$ \\
$(0.0361)$ & $(0.0361)$ \\
-0.0553 & -0.0529 \\
$(0.0412)$ & $(0.0412)$ \\
Yes & Yes \\
Yes & Yes \\
& Yes \\
1,545 & 1,545 \\
0.06 & 0.06 \\
\hline
\end{tabular}

US_BANK indicator (which equals 1 if the firm's main bank U.S. exposure is in the top half of the distribution) and the NON_US_BANK indicator (which equals 1 if the firm's main bank U.S. exposure is in the bottom half of the distribution). We find a statistically significant relation between firms' and their main banks' abnormal stock returns only for firms whose main banks are more exposed to the U.S. market. The effect is insignificant for firms whose main banks are little exposed to the U.S. market. In column 5 we include separate country/time fixed effects according to the firm's main bank exposure to the U.S. market based on the US_BANK indicator variable. In this way, we are comparing only firms with main banks that have similar exposure to the U.S. market (and within the same country and period). Results are similar to those in column 4. 
Panel B of Table 2 reports the results of the same regressions using the U.S. bailout as a separate systemic event that represented a positive shock to the financial health of U.S. banks. Columns 1-3 of Panel B indicate that the effects are similar in size to the effect of the Bear Stearns and Lehman events in Panel A. Columns 4 and 5 confirm that the relation is significant only among firms whose main banks are more exposed to the U.S. market.

\section{B. Results Using Bank-Specific Shocks}

The second type of event is bank specific, or the reporting of individual bank losses (asset write-downs). Although the occurrence of a write-down can provide the market with information about the health of a bank, it is reasonable to think that the market anticipated some of these write-downs and their levels. If this is the case, at least near the event we should not see large average effects on bank abnormal returns around write-down dates but instead see substantial variation in bank abnormal returns. We focus on weeks when there are writedowns by several banks. We estimate the relation using the sample of firms with at least one main bank experiencing a write-down during the week. In this sample, changes in banks' equity values are likely to reflect new information about their financial health. Identification comes from the fact that the market reacts differently to the write-downs of banks. We also estimate the relation using the sample of banks/weeks during the financial crisis when there were no write-downs as a benchmark. We implement this idea by estimating:

$$
\begin{aligned}
\text { FIRM_RETURN } & =\alpha_{t c g}+\beta_{0} \times \text { BANK_RETURN } \\
& +\beta_{1} \times \text { BANK_RETURN }_{i t c} \times \text { WRITE_DOWN } \\
& +\delta \times X_{i c}+\varepsilon_{i t c}
\end{aligned}
$$

where FIRM_RETURN and BANK_RETURN are weekly returns over the entire financial crisis period, $\alpha_{t c g}$ are country and write-down group and time fixed effects, WRITE_DOWN is an indicator variable that equals 1 if the firm had at least one main bank that experienced a write-down in week $t$, and $X_{i c}$ are firm-level controls measured at the end of 2006. We use the same set of control variables as in column 1 of Table 2 .

Table 3 reports results based on the estimation of equation (2). In column 1, we find a positive and significant relation between a borrower's stock returns and its main bank's stock returns when the bank had a write-down that week. There is no relation between firm and bank returns when banks did not have a write-down that week. The point estimate for the write-down group, 0.0651 $(=0.0586+0.0063)$, implies that a $40 \%$ change in the equity valuation of main banks is associated with a decline in the equity value of firms of $2.60 \%$. The magnitude of this effect is similar to the one in the sample of systemic events in Table 2.

Column 2 of Table 3 reports similar results to column 1, but we include as a control an indicator that equals 1 if the firm had a main bank that experienced a write-down in any week over the crisis period. We also include the interaction of this indicator with the bank abnormal return as a control. This ensures that 
TABLE 3

Firm Returns and Main Bank Returns: Write-Down Results

Table 3 reports coefficient estimates from regressions relating weekly firms' stock returns to their main banks' stock returns in the syndicated loan market. The dependent variable is the firm's market-model abnormal return, and the main independent variable is the average market-model abnormal return of the firm's main banks. The sample period is from July 27, 2007 to Oct. 10, 2008, and weekly returns are calculated using Friday to Friday closing prices. The WRITE_DOWN group includes only firms with at least one main bank in the syndicated loan market experiencing a write-down that week. BANK_RETURN_OTHER is the average cumulative abnormal returns of the firm's main banks in all other weeks (i.e., excluding the current week). Controls (coefficients not shown) are measured at the end of 2006 and include assets, market-to-book, leverage, cash, stock volatility, share of main bank volume during 2003-2006, share of bond issues during 2003-2006, and 1-digit Standard Industrial Classification (SIC) industry fixed effects. Alternative controls include indicator variables based on the terciles of the distribution of each control variable and 2-digit SIC industry fixed effects. The write-down any week control is an indicator variable that equals 1 if the main bank has a write-down in any week over the sample period and its interaction with the main banks' stock returns. Robust standard errors clustered at the firm level are reported in parentheses. ${ }^{* *}$ indicates significance at the $5 \%$ level.

BANK_RETURN

BANK_RETURN $\times$ WRITE_DOWN

BANK_RETURN_OTHER

BANK_RETURN_OTHER $\times$ WRITE_DOWN

Controls

Alternative controls

Country $\times$ Write-down group $\times$ Time fixed effects $\quad$ Yes Write-down any week control $\times$ Bank return

No. of obs.

$R^{2}$

our results are not driven by cross-sectional differences between banks with and without write-downs, but only by the timing of the write-downs. In columns 3 and 4 we estimate the same results using an alternative set of controls as in column 2 of Table 2. We find effects similar in size and statistical importance to the base results.

In column 5 of Table 3 we address the selection concern further. For each firm/week, we include the average cumulative abnormal return of the firm's main banks in all other weeks (i.e., excluding the current week) as an additional control variable. This controls for the overall loss of banks over the crisis, while linking firm returns and bank returns today. Perhaps banks that take larger losses are paired with firms that also take larger losses. If selection is important, we should see an important link between firms' returns and banks' overall losses in other weeks. Consistent with the view that our results are not driven by selection, we find that what matters for a firm's returns in this period is its bank's returns in this period, not its bank's returns in other periods.

\section{Cross-Sectional Results}

In this section, we examine the link between firm and bank returns for different groups of firms. Our main focus is on the importance of strong lending relationships with banks and access to public markets for explaining this link. We restrict the analysis to the sample of systemic events because of sample size considerations. 
We analyze the link between firm and bank returns across groups by estimating:

$$
\begin{aligned}
& \text { FIRM_RETURN }_{i t c}= \\
& \alpha_{t c}+\beta_{g} \times \sum_{g=1}^{k} \text { BANK_RETURN }{ }_{i t c} \times \operatorname{GROUP}(g)_{i} \\
& +\delta \times X_{i c}+\varepsilon_{i t c},
\end{aligned}
$$

where FIRM_RETURN, BANK_RETURN, and $X_{i c}$ are the same as in equation (1); $\alpha_{t c}$ are time and country fixed effects; and $\operatorname{GROUP}(g)$ is an indicator variable that equals 1 if a firm belongs to group $g$ of a firm characteristic. Estimation of this specification relates firm returns to bank returns within each time and country separately, and then averages effects across all countries and periods for each group.

\section{A. Strength of Lending Relationship}

We first estimate the link between firm and bank returns for different groups of firms according to the strength of lending relationships during 2003-2006. The first group (weak) consists of firms that have more than one main bank in the syndicated loan market (i.e., multiple banks represent the greatest share of the firm's loans) and corresponds to $37.9 \%$ of the firms in our sample. Motivated by the idea that syndicated loans cover the range between relationship lending and public debt (e.g., Dennis and Mullineaux (2000), Sufi (2007)), we classify these firms as having weak lending relationships. We then divide the remaining firms in two groups based on their share of lending with their main bank. The second group (medium) consists of firms that use more than one bank but have only one main bank in the syndicated market (i.e., one bank represents the greatest share of the firm's loans). This group represents $28.8 \%$ of the sample. The third group (strong) consists of firms that use only one bank in the syndicated loan market and represents $33.3 \%$ of the sample.

Table 4 reports the results of the three groups based on the strength of lending relationships. Column 1 reports the results with the same set of controls used in column 1 of Table 2 . We find a statistically significant relation between firms' and main banks' abnormal stock returns only for firms with strong lending relationships. The coefficient of 0.1024 for borrowers with strong lending relationships (see column 1) implies that a decline of $40 \%$ over the crisis period in the main banks' valuation is associated with a decline in borrower equity valuation of $4.10 \%$. The effect is close to 0 for firms with weak lending relationships, and positive but insignificant for firms with medium lending relationships. ${ }^{14}$

Column 2 of Table 4 reports the difference in the effect of bank returns across groups of borrower firms, including interactions of control variables with

\footnotetext{
${ }^{14}$ One concern for firms with weak lending relationships is measurement error, as we might not have correctly identified the main bank and instead related firm returns to several nonmain banks. This concern cannot explain the absence of an effect as most firms in this group have only two main banks, and less than $25 \%$ of firms in the group have more than three main banks. If the true main bank is among the banks we identify, this means we should see at least some economically important effect in this group if the correct estimate (in the absence of measurement error) is similar to the estimate for firms with strong lending relationships.
} 
TABLE 4

Effect of Strength of Lending Relationships

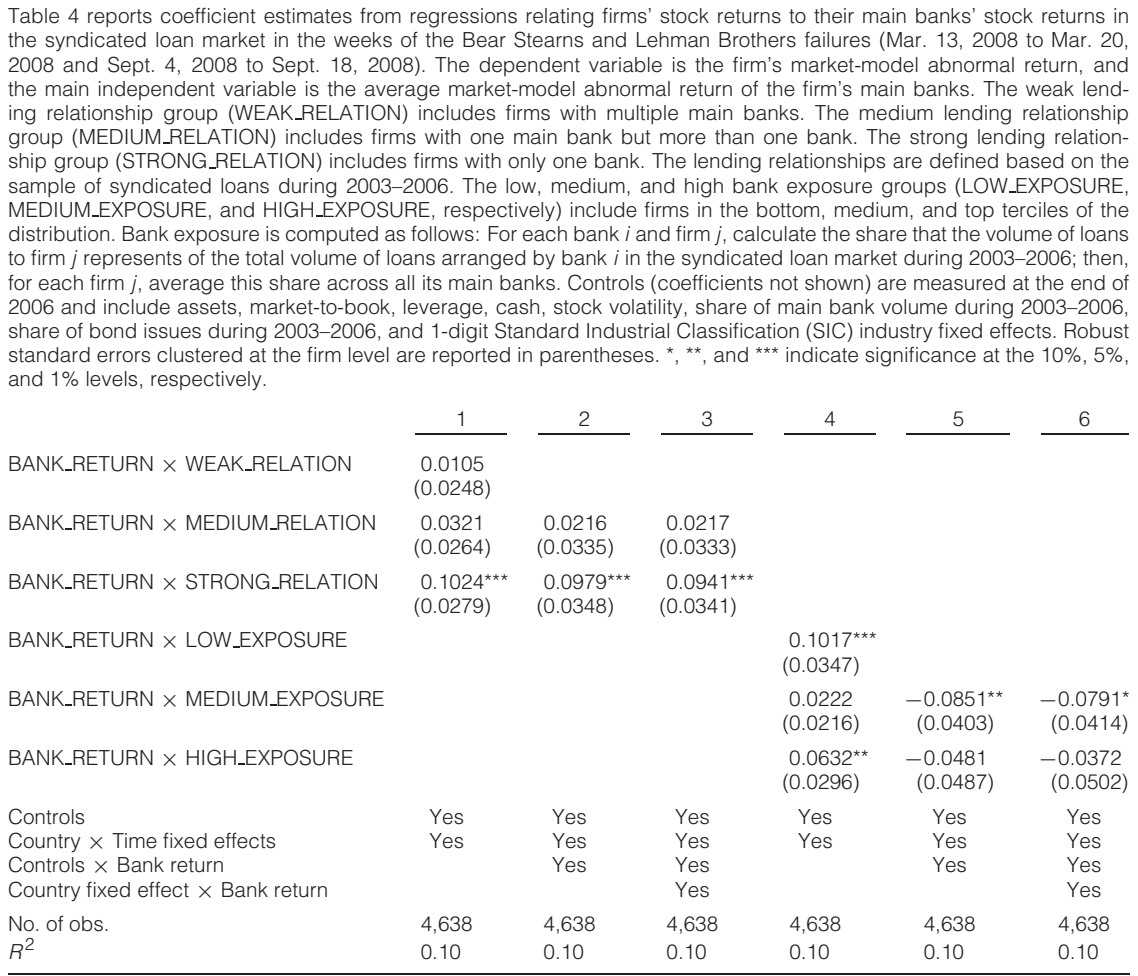

bank returns. This allows analysis of whether the differences in the effect of bank returns across groups are driven by other characteristics. The difference in effects between firms with strong and weak lending relationships is quantitatively similar to the difference in effects in column 1 . These results support the view that firms with strong lending relationships are more exposed to bank distress and that syndicated loans are closer to public debt than to relationship-driven bank loans for firms with weaker lending relationships.

Column 3 of Table 4 reports the results adding interactions of country fixed effects with bank returns to the specification in column 2 . This ensures that any comparison between groups is coming only from within-country variation in the data. In other words, the results in column 3 showing differences in the effect of bank returns across groups cannot be explained by cross-country differences in lending relationships across firms. We conclude that both cross-country and within-country variations in lending relationships lead to the same conclusions, as the results in column 3 are virtually identical to the previous results.

\section{B. Bank Exposure}

There is some concern that our results could reflect a reverse channel: The distress of important client firms leads to loss of value for banks. We examine this 
reverse channel by testing whether the relation between bank and firm returns is more important for the firms to which banks are more exposed. We measure the exposure of bank $b$ to firm $i$ using the ratio of total lending of bank $b$ to firm $i$ to total lending of bank $b$ in the syndicated loan market during 2003-2006. We then define a firm-level measure of bank exposure for each firm $i$ as the average of the exposure to firm $i$ across all banks $b$ in the set of main banks of the firm. We sort firms in our sample into three groups on the basis of the terciles of the bank exposure measure and estimate equation (3) using these three groups.

Columns 4-6 of Table 4 report the results. The relation between bank and firm returns is economically and statistically stronger for firms with lower bank exposure. The results for firms with medium exposure are weaker and statistically different from the effect for firms with low bank exposure. The results for firms with high exposure are also weaker but not statistically different from the effect for firms with low bank exposure. This provides additional support that our results are driven by the effect of main bank distress on firms and not the reverse.

\section{Firm's Access to Public Debt Markets}

In this section, we examine whether the relation between firm and bank returns is different depending on the firm's ability to access public debt markets. Firms could rely on public debt markets to offset the effect of main bank distress.

Table 5 reports the results of this analysis. For each firm, we compute the ratio of the volume of public bond issues to the volume of public bond issues plus bank loans over 2003-2006. ${ }^{15}$ Because about half of the firms in our sample do not have a public bond issue during 2003-2006 (see Panel B of Table 1), we sort firms into two groups in each specification. We first compare firms with and without any public bond issue in columns 1-3. We then compare firms in the top tercile in terms of share of public bonds with other firms in columns 4-6. As before, we add interactions of control variables with bank returns to ensure the difference in the effects of bank returns do not capture other factors. We also include interactions of country fixed effects with bank returns in some specifications. In all cases, we find no evidence of economically or statistically important differences in the effect of main bank distress between firms with and without access to public markets. In contrast, the effect of stronger lending ties with banks remains important in all specifications. This suggests that lending ties are a key determinant of bank dependence that is mostly unrelated to firms' ability to access public debt markets.

We next restrict our analysis to U.S. firms to consider an environment in which firms have easier access to public debt markets: The U.S. corporate debt market is the most developed and liquid market in the world. Column 1 of Table 6 shows that the effect of bank distress is both statistically and economically significant in the sample of U.S. firms. In columns 2 and 3 we estimate the relation between firm and main bank returns for different groups of U.S. firms according to the strength of lending relationships. We find that the effect of bank distress is

\footnotetext{
${ }^{15}$ Firms with a lower ratio of volume of public bond issues to volume of public bond issues plus bank loans rely more on bank loan financing.
} 
TABLE 5

Effect of Borrower's Access to Public Debt Markets

Table 5 reports coefficient estimates from regressions relating firms' stock returns to their main banks' stock returns in the syndicated loan market in the weeks of the Bear Stearns and Lehman Brothers failures (Mar. 13, 2008 to Mar. 20, 2008 and Sept. 4, 2008 to Sept. 18, 2008). The dependent variable is the firm's market-model abnormal return, and the main independent variable is the average market-model abnormal return of the firm's main banks. The BOND_ISSUE group includes firms that have at least one public bond issue during 2003-2006. The NO_BOND_ISSUE group includes firms that do not have any public bond issue during 2003-2006. The low/medium and high share of bond issues groups (LOW_MEDIUM_SHARE and HIGH_SHARE, respectively) include firms in the bottom/medium and top terciles of the distribution. The share of bond issues is the ratio of the volume of public bond issues to total volume of syndicated loans and public bond issues during 2003-2006. Controls (coefficients not shown) are measured at the end of 2006 and include assets, market-to-book, leverage, cash, stock volatility, share of main bank volume during 2003-2006, share of bond issues during 2003-2006, and 1-digit Standard Industrial Classification (SIC) industry fixed effects. Robust standard errors clustered at the firm level are reported in parentheses. ${ }^{*},{ }^{* *}$, and ${ }^{* \star *}$ indicate significance at the $10 \%, 5 \%$, and $1 \%$ levels, respectively.

BANK_RETURN $\times$ BOND_ISSUE

BANK_RETURN $\times$ NO_BOND_ISSUE
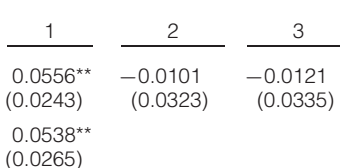

$$
4
$$

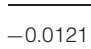

$0.0538^{\star \star}$ $(0.0265)$

BANK_RETURN $\times$ HIGH_SHARE

BANK_RETURN $\times$ LOW_MEDIUM_SHARE

BANK_RETURN $\times$ MEDIUM_RELATION

BANK_RETURN $\times$ STRONG_RELATION

Controls

Country $\times$ Time fixed effects

Controls $\times$ Bank return

Country fixed effect $\times$ Bank return

No. of obs.

$R^{2}$

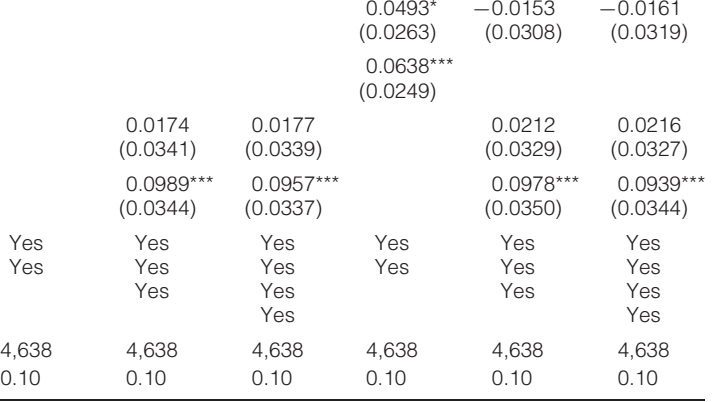

significant only in the group of stronger lending relationships, which is consistent with the results for the sample of all firms. This finding shows that our results are equally important when we restrict the sample to firms with access to the most developed and liquid capital markets in the world.

We then examine whether the relation between firm returns and main bank returns is different depending on access of U.S. firms to public debt markets. We first follow the same approach as in Table 5. Columns 4 and 5 of Table 6 compare firms that have at least one public bond issue in 2003-2006 or firms in the top tercile of the share of public bond issues in 2003-2006 with other firms. For U.S. firms, we can also use the existence of a credit rating as an alternative measure of whether firms have access to public debt markets. Faulkender and Petersen (2006) find that firms with access to bond markets (proxied by bond rating) have access to a greater supply of debt and, thus, are more highly levered. In column 6 , we use the existence of a bond rating or commercial paper rating in 2006 as indicators of a firm's ability to access to public debt markets. In column 7, we use indicators for firms with a speculative-grade rating or investment-grade rating in $2006 .{ }^{16}$

\footnotetext{
${ }^{16} \mathrm{~A}$ concern is that the existence of a bond rating is endogenous. Following Faulkender and Petersen (2006), we obtain similar results (untabulated) when we include additional control variables that are correlated with having a bond rating whether a firm is in the S\&P 500, whether the firm's
} 


\section{TABLE 6}

Effect of Strength of Lending Relationships and Borrower's Access to Public Debt Markets: U.S. Firms

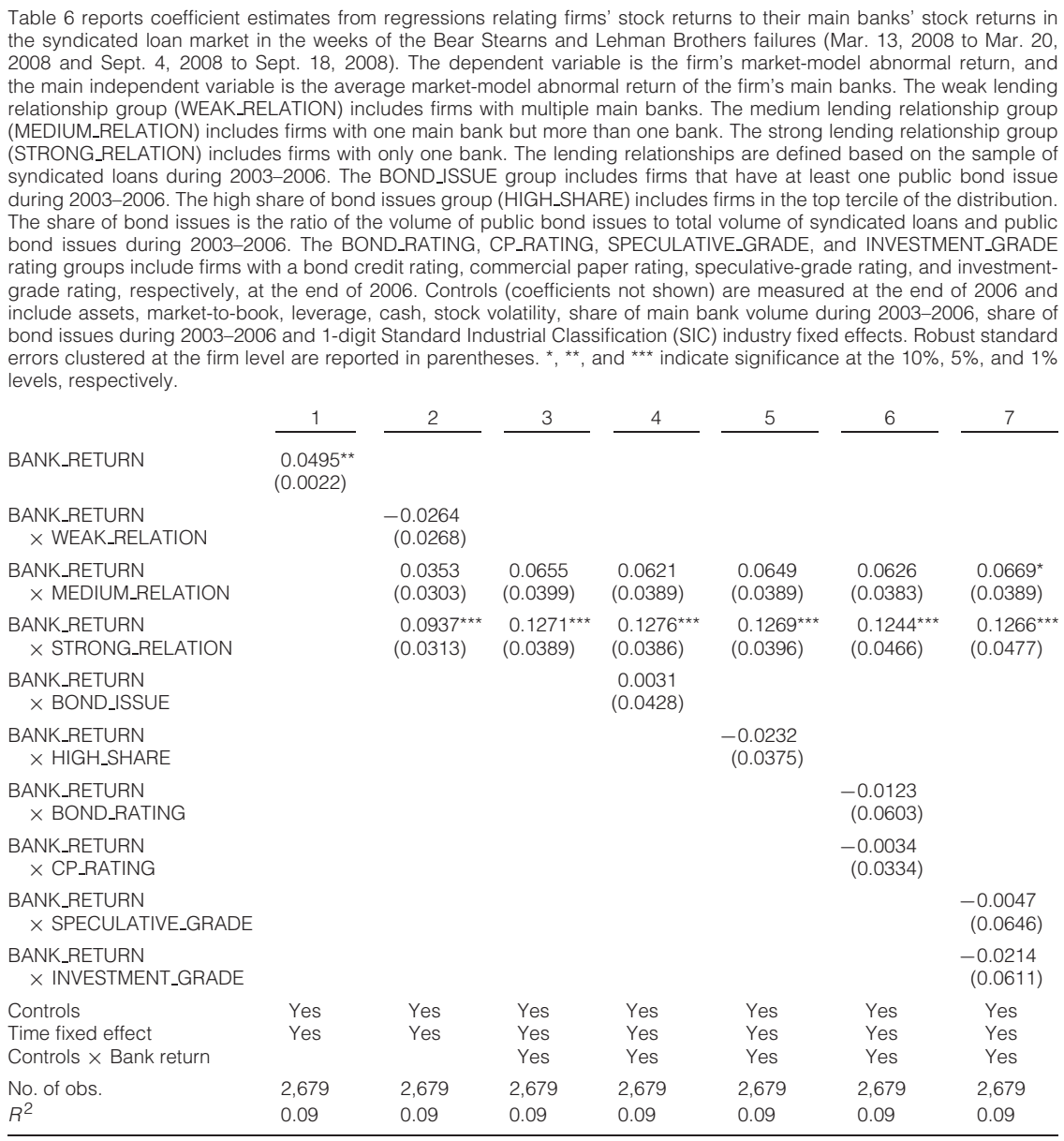

In all approaches, we find no evidence of economically or statistically important differences in the effect of main bank distress between firms with and without access to public debt markets. In contrast, the effect of stronger lending ties with banks remains important across all these approaches. Overall, the results corroborate the notion that the firms' ability to access public debt markets played a limited role in offsetting the cost of bank distress for borrowing firms during the 2007-2009 financial crisis. The results also provide evidence that stronger lending ties with banks are a distinct and important determinant of bank dependence. 
These results suggest that greater access to public markets did not help firms offset the effect of main bank distress. This finding is consistent with the view that public markets play a limited role in offsetting the cost of large aggregate shocks to the health of the banking sector for borrowing firms. When several firms want to access public markets at the same time in response to a reduction in credit supply, the supply of new funds will not be able to accommodate this demand, and the cost of raising funds in public markets might significantly increase.

Figure 2 shows an increase in corporate bond yield spreads during the recent financial crisis, which may limit the ability of public markets to offset the costs of the aggregate bank distress due to general equilibrium considerations. Although Figure 1 does not show a decrease in public debt issues during the recent crisis, the increase in public debt issues is much lower than the decline in bank loans. Because this period is likely to be associated with large shocks to firms' borrowing capacity and investment opportunities, we cannot reach clear conclusions looking only at absolute changes in debt. However, a relative increase in bond issues versus bank loans suggests an increase in the relative supply of bonds (Kashyap et al. (1993), Becker and Ivashina (2014)).

\section{Borrowers' Asymmetric Information}

In this section, we analyze how the cost of main bank distress is related to firms' information asymmetry problems. If the cost of main bank distress comes from the cost of switching banks, this cost should be more important for firms that face greater informational asymmetry problems.

We consider two proxies for borrower information asymmetry: firm size and number of analysts following a firm. We measure these variables at the end of 2006. We rank firms into three groups on the basis of terciles of distribution of firm size and number of analysts. Table 7 reports the results. We report results using both firm size and analyst coverage to capture differences in information asymmetry problems. We find a positive and significant relation between firm and bank abnormal stock returns only for borrowers in the small- and mediumfirm-size groups. Similarly, we find a positive and significant relation only for firms with low and medium coverage by analysts. These results provide additional support for the hypothesis that firms are more affected by main bank distress when lending relationships are more valuable to them (i.e., when they face more severe information asymmetry problems). This finding is consistent with evidence in Bharath et al. (2007), (2011), suggesting the importance of lending relationships for smaller publicly traded firms.

Our results so far suggest that the existence of strong lending relationships is a necessary condition for main bank distress to impose a cost on the firm. If this is really the case, greater information asymmetry problems should matter only when firms have strong lending ties with banks. In contrast, if our measure of strong lending relationships simply captures omitted factors, we might see an information asymmetry effect even among firms with weak lending relationships. We now test whether the effect of asymmetric information is important only for firms in the top two groups of lending relationships. 


\section{TABLE 7}

Effect of Strength of Lending Relationships and Asymmetric Information

\begin{tabular}{|c|c|c|c|c|}
\hline \multicolumn{5}{|c|}{ 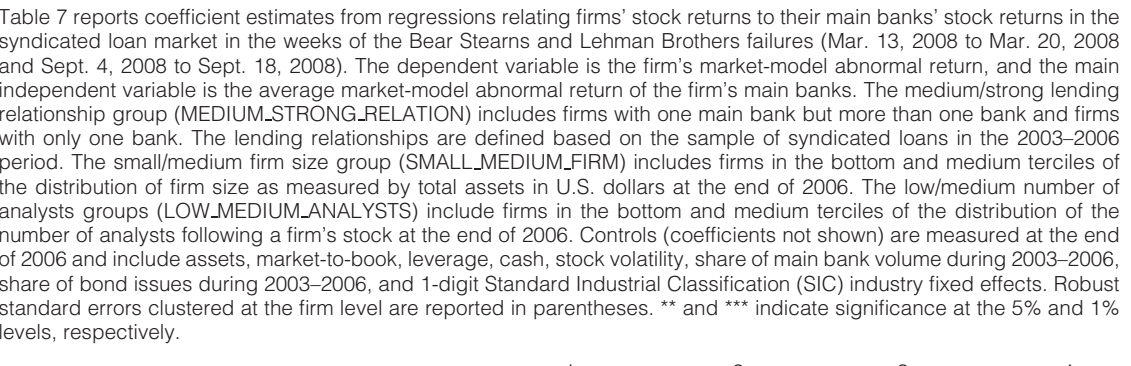 } \\
\hline & 1 & 2 & 3 & 4 \\
\hline BANK_RETURN $\times$ SMALL_MEDIUM_FIRM & $\begin{array}{l}0.0722^{\star \star} \\
(0.0304)\end{array}$ & $\begin{array}{r}-0.0357 \\
(0.0443)\end{array}$ & & \\
\hline $\begin{array}{l}\text { BANK_RETURN } \times \text { MEDIUM_STRONG_RELATION } \\
\quad \times \text { SMALL_MEDIUM_FIRM }\end{array}$ & & $\begin{array}{l}0.1349^{\star \star \star} \\
(0.0552)\end{array}$ & & \\
\hline BANK_RETURN $\times$ LOW_MEDIUM_ANALYSTS & & & $0.0916^{\star \star \star}$ & -0.0095 \\
\hline BANK_RETURN $\times$ MEDIUM_STRONG_RELATION & & & & \\
\hline$\times$ LOW_MEDIUM_ANALYSTS & & & & $(0.0509)$ \\
\hline BANK_RETURN $\times$ MEDIUM_STRONG_RELATION & & $\begin{array}{r}-0.0293 \\
(0.0412)\end{array}$ & & $\begin{array}{r}-0.0234 \\
(0.0368)\end{array}$ \\
\hline Controls & Yes & Yes & Yes & Yes \\
\hline Time fixed effects & Yes & Yes & Yes & Yes \\
\hline Controls $\times$ Bank return & Yes & Yes & Yes & Yes \\
\hline No. of obs. & 4,638 & 4,638 & 4,638 & 4,638 \\
\hline$R^{2}$ & 0.11 & 0.11 & 0.10 & 0.11 \\
\hline
\end{tabular}

The results in columns 2-4 of Table 7 show that greater information asymmetry is not associated with stronger effects of bank returns for firms with weaker lending relationships. We find that information asymmetry enhances the effect of main bank distress only for firms with medium or strong lending relationships as shown by the coefficient on the triple interaction among bank return, medium/strong lending relationship, and high information asymmetry (small- and medium-sized firms or low and medium number of analysts).

\section{E. Borrower's Financial Position}

If distress by main banks affects firms through an increase in the cost of external financing, the financial position of firms at the time of a shock should matter. We use firms' short-term debt outstanding at the end of 2007 to capture firms' need to roll over their debt during the crisis. Recent work shows that firms with debt largely maturing during the financial crisis have been the most affected by the aggregate drop in capital supply (Almeida et al. (2012)). We follow an approach similar to Almeida et al. and use firms' short-term debt outstanding at the end of 2007 (as a percentage of assets) to capture firms with debt largely maturing during the crisis. ${ }^{17}$

\footnotetext{
${ }^{17}$ Worldscope does not provide exact maturity structure and breaks down debt only into short term and long term.
} 
Column 1 of Table 8 shows a positive and significant relation between firm and bank abnormal stock returns only for borrowers in the high short-term leverage group at the end of 2007. These results support the view that firms with high levels of debt maturing in 2008 were the most affected by main bank distress.

TABLE 8

Effect of Borrower's Financial Position

Table 8 reports coefficient estimates from regressions relating firms' stock returns to their main banks' stock returns in the syndicated loan market in the weeks of the Bear Stearns and Lehman Brothers failures (Mar. 13, 2008 to Mar. 20, 2008 and Sept. 4, 2008 to Sept. 18, 2008). The dependent variable is the firm's market-model abnormal return, and the main independent variable is the average market-model abnormal return of the firm's main banks. The low, medium, and high leverage groups (LOW_LEVERAGE, MEDIUM_LEVERAGE, and HIGH_LEVERAGE, respectively) include firms in the bottom, medium, and top terciles of the distribution of the ratio of short-term debt to total assets at the end of 2007 (column 1), ratio of total debt to total assets at the end of 2007 (column 2), or ratio of total debt to total assets at the end of 2006 (column 3). The low, medium, and high cash groups (LOW_CASH, MEDIUM_CASH, and HIGH_CASH, respectively) include firms in the bottom, medium, and top terciles of the distribution of the ratio of cash to total assets at the end of 2006. Controls (coefficients not shown) are measured at the end of 2006 and include assets, market-to-book, leverage, cash, stock volatility, share of main bank volume during 2003-2006, share of bond issues during 2003-2006, and 1-digit Standard Industrial Classification (SIC) industry fixed effects. Robust standard errors clustered at the firm level are reported in parentheses. *, ${ }^{* *}$, and ${ }^{* * *}$ indicate significance at the $10 \%, 5 \%$, and $1 \%$ levels, respectively.

\begin{tabular}{|c|c|c|c|c|}
\hline & $\begin{array}{c}\text { SHORT_- } \\
\text { LEVERAGE_- } \\
2007 \\
1\end{array}$ & $\begin{array}{c}\text { LEVERAGE } \\
2007 \\
2\end{array}$ & $\begin{array}{l}\text { LEVERAGE } \\
3\end{array}$ & $\begin{array}{c}\text { CASH } \\
4\end{array}$ \\
\hline BANK_RETURN $\times$ LOW_LEVERAGE & $\begin{array}{c}0.0237 \\
(0.0228)\end{array}$ & $\begin{array}{c}0.0135 \\
(0.0286)\end{array}$ & $\begin{array}{c}0.0241 \\
(0.0292)\end{array}$ & \\
\hline BANK_RETURN $\times$ MEDIUM_LEVERAGE & $\begin{array}{c}0.0501 \\
(0.0388)\end{array}$ & $\begin{array}{c}0.0457 \\
(0.0393)\end{array}$ & $\begin{array}{l}0.0757^{* *} \\
(0.0352)\end{array}$ & \\
\hline BANK_RETURN $\times$ HIGH_LEVERAGE & $\begin{array}{l}0.0983^{\star \star} \\
(0.0455)\end{array}$ & $\begin{array}{l}0.0593^{\star \star \star} \\
(0.0235)\end{array}$ & $\begin{array}{l}0.0644^{* \star *} \\
(0.0242)\end{array}$ & \\
\hline BANK_RETURN $\times$ LOW_CASH & & & & $\begin{array}{r}0.0686^{*} \\
(0.0372)\end{array}$ \\
\hline BANK_RETURN $\times$ MEDIUM_CASH & & & & $\begin{array}{l}0.0667^{* * *} \\
(0.0260)\end{array}$ \\
\hline BANK_RETURN $\times$ HIGH_CASH & & & & $\begin{array}{c}0.0331 \\
(0.0207)\end{array}$ \\
\hline $\begin{array}{l}\text { Controls } \\
\text { Country } \times \text { Time fixed effects }\end{array}$ & $\begin{array}{l}\text { Yes } \\
\text { Yes }\end{array}$ & $\begin{array}{l}\text { Yes } \\
\text { Yes }\end{array}$ & $\begin{array}{l}\text { Yes } \\
\text { Yes }\end{array}$ & $\begin{array}{l}\text { Yes } \\
\text { Yes }\end{array}$ \\
\hline $\begin{array}{l}\text { No. of obs. } \\
R^{2}\end{array}$ & $\begin{array}{l}3,873 \\
0.11\end{array}$ & $\begin{array}{l}4,173 \\
0.11\end{array}$ & $\begin{array}{l}4,635 \\
0.09\end{array}$ & $\begin{array}{l}4,635 \\
0.09\end{array}$ \\
\hline
\end{tabular}

Recent research also shows that firms with low debt (or high cash holdings) were less affected by the aggregate change in the credit supply during the crisis (Duchin et al. (2010)). In column 2 of Table 8, we find a positive and significant relation between firm and bank abnormal stock returns for borrowers in the highleverage group at the end of 2007, whereas the relation is insignificant for firms in the medium- and low-leverage groups.

The major disadvantage of using firms' financial positions in 2007 is that firm managers might have made changes to these positions in reaction to the start of the crisis. If this is the case, our findings should be different depending on whether we use firms' financial positions in 2006 or 2007. The results in columns 3 and 4 of Table 8 sort firms using their total leverage and cash holdings at the end of 2006. These results also suggest there is no significant effect of bank distress for firms with stronger financial positions (low leverage and high cash), whereas 
there is a positive and significant effect for firms with weaker financial positions (high leverage and low cash).

\section{Additional Results and Alternative Interpretations}

In this section, we present additional results and discuss some alternative explanations for our findings. An important concern is that the link between firm returns and bank returns does not reflect the cost of main bank distress. Another concern is that strong lending relationships capture some omitted factor.

\section{A. Additional Results and Robustness}

We further analyze the effect of stronger lending ties between firms and banks. We first provide evidence that stronger lending relationships do not simply capture some omitted factor. We then show that our findings are robust across several measures of the strength of lending relationships.

To do so, we estimate equation (3) adding both the direct effect of strong lending relationships and the interaction of this effect with bank returns. The direct effect of strong lending relationships captures the effect of the systemic events on firms in the absence of main bank losses. If strong lending relationships do not capture omitted factors, we would expect strong relationships to matter only when main banks are distressed. Therefore, the direct effect of systemic events on firms should not be related to the strength of lending relationships. We test this prediction using six alternative measures of the strength of lending relationships.

The first two measures use the same groups of firms used in Table 4. We use alternative measures that capture the share of loans that firms take from their main bank (SHARE_MAIN_BANK) and the concentration of loans across all banks (HERFINDAHL_LENDING_SHARES). These two measures are calculated using loan amounts or the number of loans in the syndicated loan market from 2003 to 2006.

Table 9 reports the results. In all specifications, we find that stronger lending relationships have an economically and statistically insignificant direct effect on firms' returns. We also find that the link between bank and firm returns is significantly stronger for firms with stronger lending relationships. This conclusion is robust across all measures of the strength of lending relationships we use. The magnitudes of the effects are consistent with those in Table $4 .{ }^{18}$ Notice that, as before, we include interactions of control variables with bank returns. In untabulated results we find that there are no direct effects in any event period.

We perform additional robustness tests (untabulated) of our primary findings. A first goal is to further address the concern that stronger lending relationships might be simply capturing other omitted factors. If strong lending relationships capture omitted factors, we might see a relation between the effect of bank returns

\footnotetext{
${ }^{18}$ The coefficients in columns 1 and 2 of Table 9 are similar to the differences across groups in Table 4. Because firms in the strong group in Table 4 have one main bank, the implied effect for these firms can be computed by simply adding the effects of bank returns with the interactions of bank returns with strong lending relationships.
} 
TABLE 9

Effect of Strength of Lending Relationships: Additional Results

Table 9 reports coefficient estimates from regressions relating firms' stock returns to their main banks' stock returns in the syndicated loan market in the weeks of the Bear Stearns and Lehman Brothers failures (Mar. 13, 2008 to Mar. 20, 2008 and Sept. 4, 2008 to Sept. 18, 2008). The dependent variable is the firm's market-model abnormal return, and the main independent variable is the average market-model abnormal return of the firm's main banks. The medium/strong lending relationship group (MEDIUM_STRONG_RELATION) includes firms with one main bank but more than one bank and firms with only one bank. The lending relationships are defined based on the sample of syndicated loans during 2003-2006. Share of main bank volume and (SHARE_VOLUME) share of main bank number (SHARE_NUMBER) are the ratios of the amount and number, respectively, of loans from the main bank to total loans to a firm in the syndicated loan market during 2003-2006. Herfindahl of lending shares volume (HERFINDAHL_VOLUME) and Herfindahl of lending shares number (HERFINDAHL_NUMBER) are the Herfindahl index of lending shares based on amount and number, respectively, of loans to a firm in the syndicated loan market during 2003-2006. Controls (coefficients not shown) are measured at the end of 2006 and include assets, market-to-book, leverage, cash, stock volatility, share of main bank volume during 2003-2006, share of bond issues during 2003-2006, and 1-digit Standard Industrial Classification (SIC) industry fixed effects. Robust standard errors clustered at the firm level are reported in parentheses. ${ }^{* *}$ and ${ }^{\star \star \star}$ indicate significance at the $5 \%$ and $1 \%$ levels, respectively.

MEDIUM_STRONG_RELATION

STRONG_RELATION

SHARE_VOLUME

SHARE_NUMBER

HERFINDAHL_VOLUME

HERFINDAHL_NUMBER

BANK_RETURN

$\times$ MEDIUM_STRONG_RELATION

BANK_RETURN $\times$ STRONG_RELATION

BANK_RETURN $\times$ SHARE_VOLUME

BANK_RETURN $\times$ SHARE_NUMBER

BANK_RETURN $\times$ HERFINDAHL_VOLUME

BANK_RETURN $\times$ HERFINDAHL_NUMBER

\section{Controls}

Country $\times$ Time fixed effects

Controls $\times$ Bank return

No. of obs.

$R^{2}$

\section{$\frac{1}{-0.0027}$ \\ (0.0028) \\ 0.0005 (0.0034)}

\section{$-0.0056$ $(0.0054)$}

$-0.0016$

(0.0051)

\section{$-0.0029$}

(0.0052)

$-0.0012$

(0.0051) $0.0602^{\star \star}$

(0.0284)

$0.0840^{\star *}$

$0.1560^{\star \star \star}$

(0.0584)

$$
\begin{gathered}
0.1476^{\text {***}} \\
(0.0527)
\end{gathered}
$$

$0.1379^{\star \star \star}$ (0.0537)

$0.1381^{\star \star *}$ (0.0513)

Yes

Yes

Yes

4,638

and observable measures of firm quality and risk for firms with weak lending relationships. Alternatively, if having strong lending ties with banks is a necessary condition for the effect of bank distress, we will see such relation only for firms with strong lending ties. We find no evidence that the effect of bank distress for firms with weak lending relationships depends on observable measures of firm quality, such as returns on assets, or measures of risk, such as stock volatility and expected default frequency (EDF). ${ }^{19}$

We also estimate our main specification for periods outside the crisis, between Jan. 2007 and July 2007, for example. This provides a benchmark for

\footnotetext{
${ }^{19}$ The distance to default and EDF data are drawn from Moody's/KMV.
} 
the importance of this relation in the absence of significant news about the health of banks (a placebo test). Outside the crisis period, we find no evidence that the relation between banks' returns and firms' returns is important.

We also examine the importance of other links between firms and banks. We find that public debt or equity underwriting relationships are not driving our results. Indeed, the relation between firm and bank returns is statistically important only for firms that did not issue equity through seasoned equity offerings during 2003-2006. We also look at the presence of bankers on firms' boards of directors (Kroszner and Strahan (2001), Ferreira and Matos (2012)). We find that the relation between firm and bank returns is less important for firms when at least one main bank holds a seat on the firm's board of directors. ${ }^{20}$ This suggests that bankers on the boards of firms are not driving the results.

Finally, in untabulated results, we find evidence that distressed banks increased loan interest rate spreads during the 2007-2009 financial crisis. We follow an approach similar to Santos (2011), who shows that past bank losses predict higher loan spreads during the crisis. Because our sample includes banks from several countries, we cannot use data from the Call Reports as in Santos. Using the equity return of banks in the period preceding new loans to capture bank losses, we find evidence that bank losses also predict higher loan spreads during the crisis.

\section{B. What Drives the Link between Firm and Bank Returns?}

The first challenge stems from the possibility that firms borrowing from banks that experience greater losses are inherently different from other firms (selection problem). The value of these firms could drop more during periods of bank distress because of other cash-flow news or discount rate news. For example, if banks experience greater losses because they made poorer quality loans in the first place, we expect that firms that have relationships with these banks are at greater risk of default.

We address this concern in several ways. We control for the total abnormal cumulative return of banks over the crisis period, in addition to other firm-level controls. The idea is that once we have controlled for the total loss of banks, the cross-sectional relation between firms' and banks' abnormal returns in this period should depend on the timing of bank losses. The write-down results also address this concern. It is hard see that a selection problem would be more important in specific dates on which banks experienced write-downs. As shown in Section III.B, firms borrowing from banks with greater losses do not in general experience lower returns. Firms experience greater losses in a period only when their main bank experiences greater losses in that period and there is news about the financial health of their main bank in that period. The cross-sectional tests also help, as it is hard to see why this concern should be more important for all the groups of firms where our hypotheses predict a stronger link between banks' and firms' returns.

\footnotetext{
${ }^{20}$ Data on board members are drawn from BoardEx. For more details, see Ferreira and Matos (2012).
} 
The second challenge comes from the possibility that banks are affected by losses that their clients experience. Dahiya et al. (2003) provide evidence that financial distress by borrowers can negatively affect the value of main banks. There is a possibility that losses to a bank's corporate loan portfolio affect the bank, and this drives the relation between firm returns and bank returns over these periods. This concern could be relevant even for our write-down results, as some write-down events may have been triggered by losses in banks' portfolios of corporate loans. This interpretation of the results, however, would have different cross-sectional implications; it would predict a more pronounced effect for banks with higher exposure to firms. We find exactly the opposite in Table 4. The fact that we analyze periods with unusually large shocks to the financial health of banks also addresses this specific concern. The shocks were mostly determined by banks' exposure to mortgage and real estate assets rather than by the performance of corporate loans. Additionally, it is hard for this view to explain all of our cross-sectional results.

Finally, the third challenge is the possibility that the market can learn something about the quality of firms. If banks experience greater losses because they made poorer quality loans, the market can learn about the quality of these loan portfolios and therefore also about the banks' corporate clients. We address this concern by looking at a period of positive shocks to several banks: the U.S. bailout plan in Oct. 2008. The learning scenario cannot explain why firm value increases in response to government intervention. There should not be much learning about the quality of the banks' past lending decisions in such an event. We find, however, a similar link between firm and bank returns in the bailout sample in Panel B of Table 2.

\section{Real Effects}

In this section, we study whether strong lending relationships with banks affect real corporate behavior during the financial crisis. This allows us to corroborate that our valuation results are actually associated with real effects on firms. We do not link firms' real behavior to their main bank losses because of the lower frequency of the data.

We test whether firms with strong lending relationships cut investment more during the crisis period. We estimate the following equation:

$$
\begin{aligned}
& \text { INVESTMENT }_{i t c}=\alpha_{t c}+\beta_{0} \times \mathrm{STRONG} \mathrm{LR}_{i} \\
& +\beta_{1} \times \mathrm{STRONG} \mathrm{LR}_{i} \times \mathrm{CRISIS}+\delta \times X_{i t c}+\varepsilon_{i t c},
\end{aligned}
$$

where INVESTMENT is the ratio of annual capital expenditures to the lag of assets (Worldscope item 04601/item 02999); $\alpha_{t c}$ is a country and time fixed effect; STRONG_LR is an indicator variable that equals 1 if the firm has only one bank during 2003-2006; CRISIS is an indicator variable that equals 1 in 2007, 2008, and 2009; and $X_{i t c}$ are firm-level controls (assets, market-to-book, leverage, cash, stock volatility, share of main bank volume during 2003-2006, share of bond issues during 2003-2006, and industry indicators). We sort firms into three groups 
for each of these characteristics and include indicators for each of the groups and interactions of these indicators with the crisis indicator. Thus, our results are estimated based only on the comparison of firms sufficiently similar in terms of all these characteristics. The sample period for this test is 2000-2009. The coefficient of interest is $\beta_{1}$, which measures whether firms with strong lending relationships cut their investment more than other firms during the crisis period. ${ }^{21}$

Panel A of Table 10 reports the results. Column 1 reports the differential response of investment during the 2007-2009 financial crisis for firms with strong versus weak/medium lending relationships, which corresponds to the coefficient $\beta_{1}$ in equation (4). Firms with strong lending relationships cut yearly investment by about 1 percentage point more than other firms during the crisis, which represents $15 \%$ of the firm's precrisis average annual investment level (6.5\% of assets). Column 2 reports estimates from firm fixed-effects regressions. The estimated cut in investment during the crisis is 0.7 percentage points higher for firms with strong lending relationships relative to other firms, which represents $10 \%$ of precrisis investment levels.

Columns 3 and 4 of Table 10 replicate the results in columns 1 and 2 with an additional interaction with firm size groups. This is motivated by the valuation results in Section IV.D, where we find that having strong lending relationships matters only for small and medium firms. The results show a significant differential effect on investment during the crisis only for firms that both have stronger lending ties with banks and are smaller. There is no significant differential effect of the crisis for groups of large firms with strong lending relationships or small firms without strong lending relationships.

We also consider whether the 2007-2009 financial crisis had differential real effects on firms with greater access to public markets. The discussion in Section IV.C suggests that the ability of public debt markets to insulate firms from bank distress is limited at the time of large drops in aggregate bank lending. Figure 1 suggests that the drop in bank lending was particularly strong at the end of 2008 and thereafter. Thus, we estimate the differential effect of the crisis on investment for firms with greater access to public debt markets separately by year. We first compare firms with and without any public bond issue in columns 1 and 2 of Table 10. We then compare firms in the top tercile in terms of the share of public bonds with the other firms in columns 3 and 4 .

Panel B of Table 10 reports the results. The results suggest that firms with greater access to public debt markets were less exposed to the effects of the crisis in 2007 and 2008. However, the effect of the crisis on investment was not significantly offset by borrowers' access to public debt markets in 2009, which corresponds to the period with a stronger drop in bank lending. The effect of stronger lending ties with banks is important over the whole crisis period. In untabulated results, we find that these conclusions are robust to the use of other measures of strong lending relationships used in Table 6. We also find that these conclusions hold in a sample with only U.S. firms.

\footnotetext{
${ }^{21}$ We obtain consistent findings if we scale capital expenditures by lagged property, plant, and equipment, or use alternative sample periods (e.g., 2004-2009).
} 


\section{TABLE 10}

\section{Investment and Strength of Lending Relationships}

Table 10 reports coefficient estimates from regressions relating investment to the 2007-2009 financial crisis and strength of lending relationships. Panel A presents the basic results and Panel B presents results by year and access to public debt markets. The dependent variable is the ratio of annual capital expenditures to assets (beginning of year). The sample period is from 2000 to 2009. CRISIS is an indicator variable that equals 1 during 2007, 2008, and 2009. The strong lending relationship group (STRONG_RELATION) includes firms with only one bank in the syndicate loan market during 2003-2006. The small/medium firm size group (SMALL_MEDIUM_FIRM) includes firms in the bottom and medium terciles of the distribution of firm size as measured by total assets in U.S. dollars at the end of 2006. The NO_BOND_ISSUE group includes firms that do not have any public bond issue during 2003-2006. The low/medium share of bond issues group (LOW MEDIUM_SHARE) includes firms in the bottom and medium terciles of the distribution. The share of bond issues is the ratio of the volume of public bond issues to total volume of syndicated loans and public bond issues during 2003-2006. Controls (coefficients not shown) include indicator variables based on the terciles of the distribution of assets, market-to-book, leverage, cash, stock volatility, share of main bank volume during 2003-2006, share of bond issues during 2003-2006, 1-digit Standard Industrial Classification (SIC) industry fixed effects, and their interactions with the crisis indicator. Robust standard errors clustered at the firm level are reported in parentheses. ${ }^{*}$, ${ }^{\star \star}$, and ${ }^{\star \star \star}$ indicate significance at the $10 \%, 5 \%$, and $1 \%$ levels, respectively.

\begin{tabular}{|c|c|c|c|c|}
\hline \multirow{2}{*}{\multicolumn{5}{|c|}{ Panel A. Basic Results }} \\
\hline & & & & \\
\hline CRISIS $\times$ STRONG_RELATION & $\begin{array}{l}-0.0117^{\star \star \star} \\
(0.0036)\end{array}$ & $\begin{array}{c}-0.0072^{\star \star} \\
(0.0035)\end{array}$ & $\begin{array}{r}-0.0046 \\
(0.0048)\end{array}$ & $\begin{array}{c}0.0079 \\
(0.0049)\end{array}$ \\
\hline CRISIS $\times$ SMALL_MEDIUM_FIRM & & & $\begin{array}{c}0.0037 \\
(0.0042)\end{array}$ & $\begin{array}{c}0.0027 \\
(0.0044)\end{array}$ \\
\hline $\begin{array}{l}\text { CRISIS } \times \text { STRONG_RELATION } \\
\quad \times \text { SMALL_MEDIUM_FIRM }\end{array}$ & & & $\begin{array}{l}-0.0205^{\star \star \star} \\
(0.0062)\end{array}$ & $\begin{array}{c}-0.0192^{* * *} \\
(0.0063)\end{array}$ \\
\hline $\begin{array}{l}\text { Controls } \\
\text { Country } \times \text { Time fixed effects } \\
\text { Industry } \times \text { Time fixed effects } \\
\text { Firm fixed effects }\end{array}$ & $\begin{array}{l}\text { Yes } \\
\text { Yes } \\
\text { Yes }\end{array}$ & $\begin{array}{l}\text { Yes } \\
\text { Yes } \\
\text { Yes } \\
\text { Yes }\end{array}$ & $\begin{array}{l}\text { Yes } \\
\text { Yes } \\
\text { Yes }\end{array}$ & $\begin{array}{l}\text { Yes } \\
\text { Yes } \\
\text { Yes } \\
\text { Yes }\end{array}$ \\
\hline $\begin{array}{l}\text { No. of obs. } \\
R^{2}\end{array}$ & $\begin{array}{c}13,316 \\
0.11\end{array}$ & $\begin{array}{c}13,316 \\
0.23\end{array}$ & $\begin{array}{c}13,316 \\
0.12\end{array}$ & $\begin{array}{c}13,316 \\
0.25\end{array}$ \\
\hline \multicolumn{5}{|c|}{ Panel B. Results by Year and Access to Public Debt Markets } \\
\hline YR2007 × NO_BOND_ISSUE & $\begin{array}{r}-0.0071^{*} \\
(0.0037)\end{array}$ & $\begin{array}{r}-0.0069^{*} \\
(0.0037)\end{array}$ & & \\
\hline YR2008 × NO_BOND_ISSUE & $\begin{array}{l}-0.0155^{\star \star \star} \\
(0.0044)\end{array}$ & $\begin{array}{l}-0.0155^{\star \star \star} \\
(0.0044)\end{array}$ & & \\
\hline YR2009 × NO_BOND_ISSUE & $\begin{array}{r}-0.0023 \\
(0.0042)\end{array}$ & $\begin{array}{r}-0.0026 \\
(0.0045)\end{array}$ & & \\
\hline YR2007 × LOW_MEDIUM_SHARE & & & $\begin{array}{r}-0.0017 \\
(0.0042)\end{array}$ & $\begin{array}{r}-0.0069^{*} \\
(0.0037)\end{array}$ \\
\hline YR2008 × LOW_MEDIUM_SHARE & & & $\begin{array}{c}-0.0100^{\star \star} \\
(0.0044)\end{array}$ & $\begin{array}{l}-0.0155^{\star \star \star} \\
(0.0044)\end{array}$ \\
\hline YR2009 × LOW_MEDIUM_SHARE & & & $\begin{array}{c}0.0031 \\
(0.0034)\end{array}$ & $\begin{array}{r}-0.0026 \\
(0.0045)\end{array}$ \\
\hline $\begin{array}{l}\text { YR2007 × STRONG_RELATION } \\
\quad \times \text { SMALL_MEDIUM_FIRM }\end{array}$ & $\begin{array}{l}-0.0191^{\star \star \star} \\
(0.0075)\end{array}$ & $\begin{array}{l}-0.0172^{\star \star \star} \\
(0.0075)\end{array}$ & $\begin{array}{l}-0.0194^{\star \star \star} \\
(0.0075)\end{array}$ & $\begin{array}{l}-0.0171^{\star * \star} \\
(0.0075)\end{array}$ \\
\hline $\begin{array}{l}\text { YR2008 } \times \text { STRONG_RELATION } \\
\times \text { SMALL_MEDIUM_FIRM }\end{array}$ & $\begin{array}{l}-0.0205^{\star \star \star} \\
(0.0082)\end{array}$ & $\begin{array}{l}-0.0181^{\star \star \star} \\
(0.0081)\end{array}$ & $\begin{array}{l}-0.0207^{\star \star \star} \\
(0.0082)\end{array}$ & $\begin{array}{l}-0.0179^{\star * *} \\
(0.0081)\end{array}$ \\
\hline $\begin{array}{l}\text { YR2009 } \times \text { STRONG_RELATION } \\
\times \text { SMALL_MEDIUM_FIRM }\end{array}$ & $\begin{array}{l}-0.0217^{\star \star \star} \\
(0.0076)\end{array}$ & $\begin{array}{l}-0.0219^{\star \star \star} \\
(0.0077)\end{array}$ & $\begin{array}{l}-0.0219^{\star \star \star} \\
(0.0076)\end{array}$ & $\begin{array}{l}-0.0219^{* \star *} \\
(0.0077)\end{array}$ \\
\hline $\begin{array}{l}\text { Controls } \\
\text { Country } \times \text { Time fixed effects } \\
\text { Industry } \times \text { Time fixed effects } \\
\text { Firm fixed effects }\end{array}$ & $\begin{array}{l}\text { Yes } \\
\text { Yes } \\
\text { Yes }\end{array}$ & $\begin{array}{l}\text { Yes } \\
\text { Yes } \\
\text { Yes } \\
\text { Yes }\end{array}$ & $\begin{array}{l}\text { Yes } \\
\text { Yes } \\
\text { Yes }\end{array}$ & $\begin{array}{l}\text { Yes } \\
\text { Yes } \\
\text { Yes } \\
\text { Yes }\end{array}$ \\
\hline $\begin{array}{l}\text { No. of obs. } \\
R^{2}\end{array}$ & $\begin{array}{c}13,316 \\
0.11\end{array}$ & $\begin{array}{c}13,316 \\
0.23\end{array}$ & $\begin{array}{c}13,316 \\
0.12\end{array}$ & $\begin{array}{c}13,316 \\
0.25\end{array}$ \\
\hline
\end{tabular}

Overall, the results suggest that our valuation effects are matched to drops in investment by firms with strong lending ties with banks. The results are consistent with the view that public debt markets can play a limited role in offsetting the costs of bank distress during periods of large aggregate drops in bank lending. 


\section{Conclusion}

In this article, we examine the cross-sectional determinants of the contagion from distressed banks to borrowing firms using a large sample of publicly listed firms from 34 countries during the 2007-2009 financial crisis. We identify periods when relationship banks experienced major but different levels of unexpected distress stemming from systemic events (the failures of Bear Stearns and Lehman Brothers) and bank-specific events (asset write-downs).

Our contribution is twofold. First, we find an important link between unexpected relationship bank distress and losses to the market value of borrower firms. We provide direct evidence for the hypothesis that the strength of firms' lending ties with banks is a key determinant of the degree of bank dependence. Because most firms in the overall economy do not have access to public capital markets, it is important to understand other determinants of bank dependence. Second, we examine the value of public debt markets in insulating firms from bank distress during a period of large aggregate losses to financial institutions and large aggregate drops in bank lending. We conclude that public debt markets play a limited role in offsetting the cost of bank distress for borrowing firms in such an environment. We also provide evidence that bank distress is associated with economically important reductions in corporate investment for firms with stronger lending relationships and that the ability to access public debt markets does not allow firms to offset investment drops during periods of large drops in bank loans.

Our results have potential policy implications. Because firms have economic value tied to their relationship banks, changes in the financial conditions of banks can have sizable externalities. Since these externalities are not likely to be internalized by those financing the banks, regulators should consider the costs for the real economy when they design policies to stabilize the financial system. Our results provide guidance on when these externalities are likely to be most important.

\section{References}

Almeida, H.; M. Campello; B. Laranjeira; and S. Weisbenner. "Corporate Debt Maturity and the Real Effects of the 2007 Credit Crisis." Critical Finance Review, 1 (2012), 3-58.

Bae, K.; J. Kang; and C. Lim. "The Value of Durable Relationships: Evidence from Korean Banking Shocks." Journal of Financial Economics, 64 (2002), 181-214.

Becker, B., and V. Ivashina. "Cyclicality of Credit Supply: Firm Level Evidence.” Journal of Monetary Economics, 62 (2014), 76-93.

Bernanke, B. "Nonmonetary Effects of the Financial Crisis in the Propagation of the Great Depression." American Economic Review, 73 (1983), 257-276.

Bernanke, B. "The Financial Accelerator and the Credit Channel." Presented at the Credit Channel of Monetary Policy in the 21st Century Conference, Federal Reserve Bank of Atlanta, Atlanta, GA (2007).

Bharath, S.; S. Dahiya; A. Saunders; and A. Srinivasan. "So What Do I Get? The Bank's View of Lending Relationships.” Journal of Financial Economics, 85 (2007), 368-419.

Bharath, S.; S. Dahiya; A. Saunders; and A. Srinivasan. "Lending Relationships and Loan Contract Terms." Review of Financial Studies, 24 (2011), 1141-1203.

Boot, A.; S. Greenbaum; and A. Thakor. "Reputation and Discretion in Financial Contracting." American Economic Review, 83 (1993), 1165-1183.

Brunnermeier, M. "Deciphering the Liquidity and Credit Crunch 2007-2008." Journal of Economic Perspectives, 23 (2009), 77-100. 
Calomiris, C., and J. Mason. “Consequences of U.S. Bank Distress During the Depression.” American Economic Review, 93 (2003), 937-947.

Campello, M.; E. Giambona; J. Graham; and C. Harvey. "Liquidity Management and Corporate Investment during a Financial Crisis." Review of Financial Studies, 24 (2011), 1944-1979.

Chava, S., and A. Purnanandam. "The Effect of Banking Crisis on Bank Dependent Borrowers." Journal of Financial Economics, 99 (2011), 116-135.

Cohen, L., and A. Frazzini. "Economic Links and Predictable Returns.” Journal of Finance, 63 (2008), 1977-2011.

Dahiya, S.; A. Saunders; and A. Srinivasan. "Financial Distress and Bank Lending Relationships." Journal of Finance, 58 (2003), 375-399.

Dennis, S., and D. Mullineaux. "Syndicated Loans." Journal of Financial Intermediation, 9 (2000), 404-426.

Detragiache, E.; P. Garella; and L. Guiso. "Multiple versus Single Banking Relationships: Theory and Evidence." Journal of Finance, 55 (2000), 1133-1161.

Diamond, D. "Financial Intermediation and Delegated Monitoring." Review of Economic Studies, 51 (1984), 393-414.

Diamond, D. "Monitoring and Reputation: The Choice between Bank Loans and Directly Placed Debt.” Journal of Political Economy, 99 (1991), 689-721.

Duchin, R.; O. Ozbas; and B. Sensoy. "Costly External Finance, Corporate Investment and the Subprime Mortgage Financial Crisis.” Journal of Financial Economics, 97 (2010), 418-435.

Faulkender, M., and M. Petersen. "Does the Source of Capital Affect Capital Structure?" Review of Financial Studies, 19 (2006), 45-79.

Fernando, C.; A. May; and W. Megginson. "The Value of Investment Banking Relationships: Evidence from the Collapse of Lehman Brothers." Journal of Finance, 67 (2012), 235-270.

Ferreira, M., and P. Matos. "Universal Banks and Corporate Control: Evidence from the Global Syndicated Market.” Review of Financial Studies, 25 (2012), 2703-2744.

Gorton, G., and A. Metrick. "Securitized Banking and the Run on the Repo." Journal of Financial Economics, 104 (2012), 425-451.

Holmstrom, B., and J. Tirole. "Financial Intermediation, Loanable Funds and the Real Sector." Quarterly Journal of Economics, 112 (1997), 663-691.

Hoshi, T.; A. Kashyap; and D. Scharfstein. "The Role of Banks in Reducing the Costs of Financial Distress in Japan.” Journal of Financial Economics, 27 (1990), 67-88.

Ibbotson Associates. Stocks, Bonds, Bills, and Inflation: 2009 Yearbook. Chicago, IL: Morningstar (2009).

Ivashina, V., and D. Scharfstein. "Bank Lending during the Financial Crisis of 2008." Journal of Financial Economics, 97 (2010), 319-338.

Kashyap, A.; O. Lamont; and J. Stein. "Credit Conditions and the Cyclical Behavior of Inventories." Quarterly Journal of Economics, 109 (1994), 565-592.

Kashyap, A.; J. Stein; and D. Wilcox. "Monetary Policy and Credit Conditions: Evidence from the Composition of External Finance.” American Economic Review, 83 (1993), 78-98.

Khwaja, A., and A. Mian. "Tracing the Impact of Bank Liquidity Shocks: Evidence from an Emerging Market.” American Economic Review, 98 (2008), 555-599.

Kroszner, R., and P. Strahan. "Bankers on Boards: Monitoring Conflicts of Interest, and Lender Liability.” Journal of Financial Economics, 62 (2001), 415-452.

Leary, M. "Bank Loan Supply, Lender Choice and Corporate Capital Structure." Journal of Finance, 63 (2008), 2013-2059.

Ongena, S.; D. Smith; and D. Michalsen. "Firms and Their Distressed Banks: Evidence from the Norwegian Banking Crisis.” Journal of Financial Economics, 67 (2003), 81-112.

Paravisini, D., "Local Bank Financial Constraints and Firm Access to External Finance." Journal of Finance, 63 (2008), 2161-2193.

Petersen, M., and R. Rajan. "The Benefits of Lending Relationships: Evidence from Small Business Data.” Journal of Finance, 49 (1994), 3-37.

Petersen, M., and R. Rajan. "The Effect of Credit Market Competition on Lending Relationships." Quarterly Journal of Economics, 110 (1995), 406-443.

Puri, M.; J. Rocholl; and S. Steffen. "Global Retail Lending in the Aftermath of the U.S. Financial Crisis: Distinguishing between Supply and Demand Effects." Journal of Financial Economics, 100 (2011), 556-578.

Rajan, R. "Insiders and Outsiders: The Choice between Informed and Arm's Length Debt." Journal of Finance, 47 (1992), 1367-1400.

Santos, J. "Bank Loan Pricing Following the Subprime Crisis." Review of Financial Studies, 24 (2011), 1916-1943.

Schnabl, P. "The International Transmission of Bank Liquidity Shocks: Evidence from an Emerging Market.” Journal of Finance, 67 (2012), 897-932. 
Sharpe, S. "Asymmetric Information, Bank Lending, and Implicit Contracts: A Stylized Model of Customer Relationships.” Journal of Finance, 45 (1990), 1069-1087.

Slovin, M.; M. Sushka; and J. Polonchek. "The Value of Bank Durability: Borrowers as Bank Stakeholders." Journal of Finance, 48 (1993), 247-266.

Sufi, A. "Information Asymmetry and Financing Arrangements: Evidence from Syndicated Loans." Journal of Finance, 62 (2007), 1057-1088.

Veronesi, P., and L. Zingales. "Paulson's Gift.” Journal of Financial Economics, 97 (2010), 339-368. 